\title{
Flexibility in Antarctic krill Euphausia superba decouples diet and recruitment from overwinter sea-ice conditions in the northern Antarctic Peninsula
}

\author{
Jennifer Walsh*, Christian S. Reiss, George M. Watters \\ Antarctic Ecosystem Research Division, Southwest Fisheries Science Center, National Marine Fisheries Service, \\ National Oceanic and Atmospheric Administration, La Jolla, CA 92037, USA
}

\begin{abstract}
Winter sea-ice conditions are considered important for Antarctic krill Euphausia superba survival and recruitment, yet few broad-scale longitudinal studies have examined the underlying relationships between winter conditions and krill recruitment. We used data from a 4 yr winter study of krill condition (lipid content), diet (stable isotopes and fatty acids), and length distributions around the northern Antarctic Peninsula to examine relationships among environmental variables (annual sea-ice cover, water column chlorophyll a [chl a], and upper mixed-layer water temperature), the condition and diet of krill, and recruitment success the following year. Diet indicators (lipid content, $\delta^{15} \mathrm{~N}, \delta^{13} \mathrm{C}$, and the fatty acid ratios $16: 1 \mathrm{n}-7 / 18: 4 \mathrm{n}-3$ and $18: 1 \mathrm{n}-9 / 18: 1 \mathrm{n}-7$ ) in postlarvae were consistent among years regardless of seaice cover, suggesting that post-larval krill do not rely on sea-ice resources for overwinter survival. Diet indicators in larvae were more variable and suggest that larvae may feed on sea-ice resources when they are available but can still persist in the water column when they are not. Principal component analysis between environmental variables and diet indicators showed that water-column chl a was the only variable that significantly affected diet, regardless of annual changes in sea-ice cover. Extensive winter ice in one year did not translate into successful recruitment the following year. Krill demonstrate a high degree of flexibility with respect to overwinter habitat and diet, and the degree to which sea ice is important during different times of year and at different life stages may be more complex than previously thought.
\end{abstract}

KEY WORDS: Antarctic krill $\cdot$ Chlorophyll $\cdot$ Diet · Overwinter survival $\cdot$ Recruitment $\cdot$ Sea ice

\footnotetext{
${ }^{*}$ Corresponding author: jen.walsh@noaa.gov
}

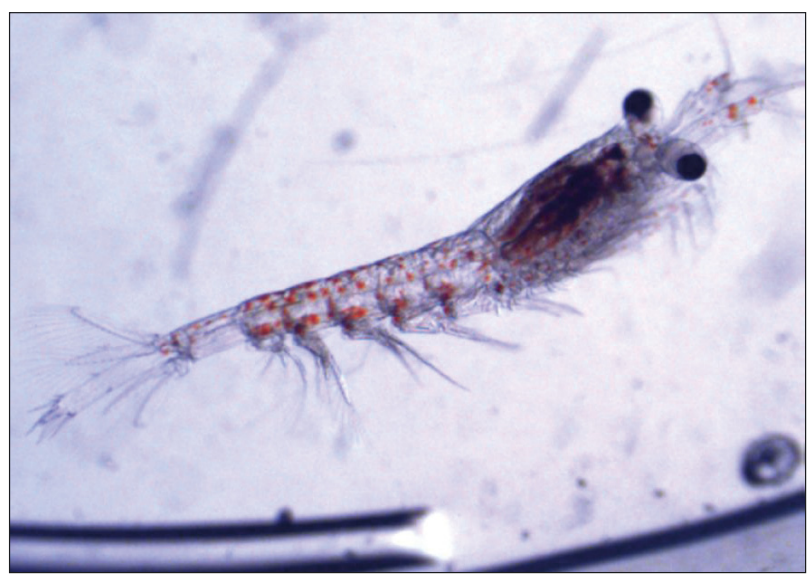

Antarctic krill Euphausia superba larvae have flexible diets during winter and feed in both sea ice and the water column.

Photo: Rob King, Australian Antarctic Division

\section{INTRODUCTION}

Antarctic krill Euphausia superba (hereafter 'krill') are a critical resource for Antarctic predators (Atkinson et al. 2004, Quetin et al. 2007, Flores et al. 2012), a key biological component of the carbon cycle (Le Fevre et al. 1998), and the target of a commercial fishery (Nicol et al. 2011). Krill have been extensively studied during summer, when they rely on seasonal phytoplankton blooms for nutrition and to fuel growth and spawning (Quetin \& Ross 1991, 2009, Meyer 2012). We know less about the overwintering strategies of krill, specifically about the functional relationships between krill life stages and the biolog-

Outside the USA, (C) the US Government (2020). Open Access under Creative Commons by Attribution Licence. Use, distribution and reproduction are unrestricted. Authors and original publication must be credited.

Publisher: Inter-Research · www.int-res.com 
ical and physical aspects of sea ice. Competing hypotheses concerning these relationships have emerged over time, from those suggesting that seaice resources are important for overwintering krill (e.g. Daly 1990, Meyer et al. 2002, 2009, 2017 , Kohlbach et al. 2017, Schaafsma et al. 2017), to those suggesting that alternative food resources can sustain krill throughout winter (e.g. Huntley et al. 1994, Daly 2004, Schmidt et al. 2014, Jia et al. 2016). These hypotheses continue to be refined as we learn more about regional differences in the winter habitats occupied by krill and the physiological and behavioral responses of krill to environmental variability.

The circumpolar distribution of krill and the wide variation in local habitats throughout the Southern Ocean indicate that different functional populations of krill experience a broad range of winter conditions. Winters at South Georgia are largely ice-free, while the Lazarev and Weddell Seas are consistently covered in pack ice during winter (Siegel et al. 1990, Siegel 2012, Flores et al. 2014). Variability in sea-ice extent around east Antarctica is largely determined by annual patterns in ocean circulation (Nicol et al. 2000), while the highly variable nature of winter seaice extent around the western Antarctic Peninsula is largely attributable to changes in atmospheric circulation (Harangozo 2006). Despite the regional differences in ice cover across the Southern Ocean, multiple studies have shown that association with sea ice during winter imparts an advantage on larvae during this critical period in the life history of krill, increasing their ability to survive their first winter and recruit to the adult population (Marschall 1988, Daly 1990, Siegel \& Loeb 1995, Meyer et al. 2009, Kohlbach et al. 2017, Schaafsma et al. 2017).

The benefit to krill of overwintering in sea ice is feeding on sea-ice-associated microbial communities (SIMCOs), which are considered a critical resource for both post-larval and larval (furcilia IV-VI) krill (Quetin \& Ross 1991, Siegel \& Loeb 1995, Atkinson et al. 2004, Flores et al. 2012). Because of limited sunlight, extensive ice cover, and deep vertical mixing in ice-free areas, primary productivity is low throughout the Southern Ocean during winter (Vernet et al. 2008), and SIMCOs are thought to provide nutritional resources for overwinter survival in the absence of abundant phytoplankton in the water column (Stretch et al. 1988, Siegel 1989, Atkinson et al. 2004, Flores et al. 2012, Kohlbach et al. 2017, Schaafsma et al. 2017). While post-larvae may decrease their reliance on seaice biota by reducing their metabolism and feeding activity and simultaneously increasing their reliance on lipid stores (Quetin \& Ross 1991, Hagen et al. 2001,
Meyer et al. 2010, Virtue et al. 2016), larvae are largely regarded as reliant on sea-ice biota because they lack high lipid stores and need to feed during winter to survive, grow, and recruit (Daly 1990, Quetin \& Ross 1991, Meyer et al. 2002). Higher growth rates and lipid concentrations have been found in larvae associated with SIMCOs compared to those in open water during winter (Ross \& Quetin 1991, Quetin et al. 2003, Daly 2004, Meyer et al. 2009).

Several studies have directly linked the duration of winter sea-ice extent with successful recruitment the following year (Siegel \& Loeb 1995, Loeb et al. 1997, Quetin \& Ross 2003, Saba et al. 2014). When ice forms earlier in the season, it may incorporate more particulate organic matter (POM) from the water column, leading to the initial development of SIMCOs (Quetin et al. 2007). Early forming ice that persists into late winter and early spring promotes early maturation and spawning of adult krill because of the seeding effect of SIMCOs released from melting ice in spring (Quetin et al. 2007). Early spawning may result in higher larval survival because of the increased length of time larvae have to feed and develop before winter (Siegel \& Loeb 1995). Ice not only provides the necessary food resources for larvae to survive the winter, but also provides critical protection from predation (Siegel \& Loeb 1995).

The extent to which sea-ice resources are used by krill during winter may be reflected in trophic biomarkers. Ratios of carbon isotopes $\left({ }^{12} \mathrm{C} /{ }^{13} \mathrm{C}\right.$, denoted as $\delta^{13} \mathrm{C}$ ) in consumer tissues can be used to infer dietary carbon sources and feeding habitat, while ratios of nitrogen isotopes $\left({ }^{14} \mathrm{~N} /{ }^{15} \mathrm{~N}\right.$, denoted as $\left.\delta^{15} \mathrm{~N}\right)$ in consumer tissues reflect trophic position. Specifically, sea-ice resources are characterized by more positive values of $\delta^{13} \mathrm{C}$ than water-column resources (Frazer 1996, Jia et al. 2016), while higher values of $\delta^{15} \mathrm{~N}$ reflect higher trophic position; consumer tissue is enriched in $\delta^{15} \mathrm{~N}(2-5 \%)$ relative to prey (Stowasser et al. 2012). Krill feeding on ice algae may have lower $\delta^{15} \mathrm{~N}$ than krill consuming more heterotrophic diets (Kohlbach et al. 2017).

While stable isotopes are valuable for discerning carbon sources and trophic position, fatty acids are useful for inferring specific prey groups (Schmidt et al. 2006). Fatty acids from prey may be deposited largely unaltered into consumer tissues, providing a record of diet over time (Budge et al. 2006). Ratios of particular fatty acids can be used to discriminate between prey common to specific habitats. For example, high ratios of 16:1n-7/18:4n-3 suggest increased consumption of diatoms over flagellates (Stübing \& Hagen 2003). Higher consumption of diatoms may 
reflect increased feeding on sea-ice resources (Garrison \& Close 1993), while higher consumption of flagellates may reflect increased feeding on watercolumn resources (Garrison et al. 1993).

Because stable isotopes and fatty acids have different turnover rates, it is possible to distinguish between diets consumed in late autumn/early winter and in mid- to late winter. Carbon and nitrogen turnover in larvae occurs during winter over periods of several weeks to months (Frazer et al. 1997), while lipids decrease more rapidly and may reach levels as low as $5 \%$ in approximately $24 \mathrm{~d}$ (Meyer et al. 2002). Percentages of certain fatty acids in larvae may reflect changes in diet in as few as $10 \mathrm{~d}$ (Stübing et al. 2003).

Although biomarkers are useful for studying diet, metabolic differences associated with the overwintering strategies of different life stages (Meyer 2012) may preclude comparisons of trophic biomarkers between post-larvae and larvae. Different energy requirements during winter result in rapid lipid turnover rates in larvae compared to post-larvae (Meyer et al. 2002), suggesting that fatty acids may reflect dietary shifts sooner in larvae. Additionally, certain fatty acids (e.g. 18:1n-9) are correlated with total lipid (Schmidt et al. 2006), meaning that some fatty acid ratios (e.g. 18:1n-9/18:1n-7 for evaluating degree of carnivory; Stübing et al. 2003) may be lower in larvae than in post-larvae but still may be useful for evaluating changes in diet among years within the same life stage.

We surveyed an important spawning and recruitment area around the northern Antarctic Peninsula $\left(125000 \mathrm{~km}^{2}\right)$ during the winters of 2013-2016 (see Fig. 1; Table S1 in the Supplement 1 at www.intres.com/articles/suppl/m642p001_supp1.xlsx). Sampling a consistent survey grid allowed us to evaluate the effects of environmental variability on the condition, diet, and recruitment success of larval krill. Body lipid content was used to examine the condition of krill and to evaluate their overall nutritive status. Fatty acid markers were used to evaluate relative contributions of carnivorous and autotrophic prey, and of particular prey groups, while $\delta^{13} \mathrm{C}$ was used to evaluate the contribution of sea-ice resources to diet, and $\delta^{15} \mathrm{~N}$ was used to evaluate the relative trophic position of krill.

Our goal was to investigate annual differences in the condition and diet of krill, and to relate these differences to environmental conditions. We predicted that annual ice cover would be the primary influence on observed differences in diet among years, and that larval krill associated with ice would have higher lipid content. We also predicted that we would observe high proportional recruitment in years following winters of favorable ice conditions, when larvae were presumably in good condition from feeding on SIMCOs.

\section{MATERIALS AND METHODS}

\subsection{Survey area and general survey design}

The US Antarctic Marine Living Resources (AMLR) Program conducted 4 winter surveys (August and September 2013-2016) around the northern Antarctic Peninsula aboard the research vessel/ice breaker (RVIB) 'Nathaniel B. Palmer'. A description of the bathymetry and circulation around the survey area is provided in Reiss et al. (2015). Sampled stations were part of a historical grid of 110 fixed stations (approximately 20-40 km apart) divided into 4 sampling sectors: Elephant Island ( $\mathrm{EI}_{;} 43865 \mathrm{~km}^{2}$ ), Joinville Island $\left(\mathrm{JI} ; 18151 \mathrm{~km}^{2}\right)$, Bransfield Strait ('South Area', SA; $24479 \mathrm{~km}^{2}$ ), and the area immediately north of Livingston and King George Islands ('West Area', WA; $38524 \mathrm{~km}^{2}$ ) (Fig. 1). Time limitations, inclement weather, and thick ice precluded sampling all stations in some years; however, we sampled all survey sectors each year.

\subsection{At-sea sampling}

At each station, we performed a CTD cast (SBE9/11; $\mathrm{SBE}$ ) to $750 \mathrm{~m}$ or within $10 \mathrm{~m}$ of the bottom in shallower areas. The CTD was equipped with 24 Niskin bottles (10 l) that collected sea water on upcasts at $750,200,100,75,50,40,30,20,15$, and $5 \mathrm{~m}$. The upper mixed layer (UML; $\mathrm{m}$ ) was defined from CTD profiles as the depth at which the water density changed by $0.05 \mathrm{~kg} \mathrm{~m}^{-3}$ relative to the average density of the upper $10 \mathrm{~m}$ of the water column (Mitchell \& Holm-Hansen 1991). UML water temperature and salinities were defined as the average of the temperatures and salinities over the depth of the UML.

Water samples $(250 \mathrm{ml})$ from each CTD bottle were filtered through $25.4 \mathrm{~mm}$ Whatman GF/F filters and used to determine the chlorophyll a ( $\mathrm{chl}$ a) concentration within the water column at discrete depths following methods outlined in Holm-Hansen et al. (1965). We calculated integrated chl a (to $100 \mathrm{~m}, \mathrm{mg}$ $\mathrm{chl} a \mathrm{~m}^{-2}$; hereafter $\mathrm{chl} a$ ) at each station as a measure of primary production and an indicator of water column food availability (Quetin et al. 2007). 


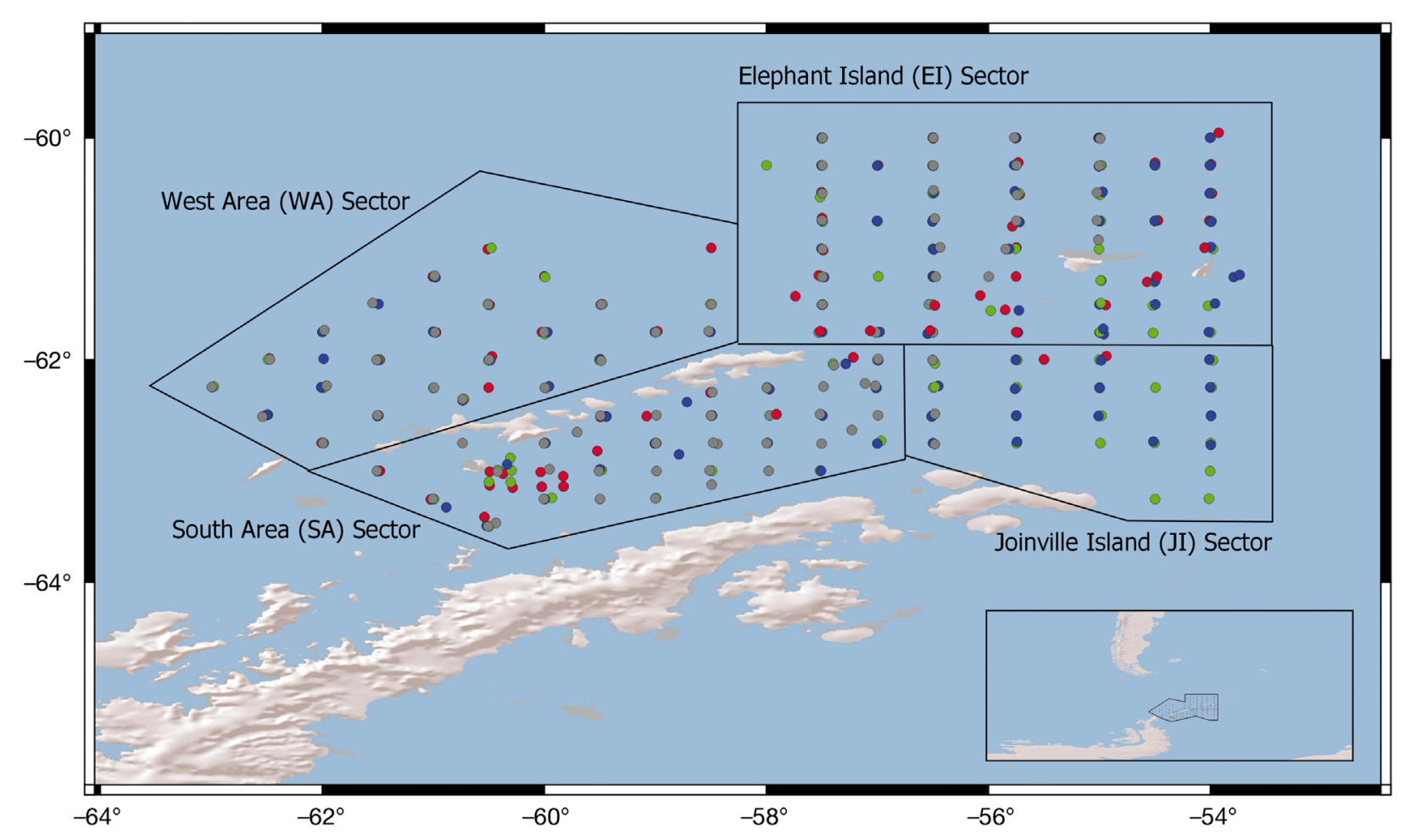

Fig. 1. US Antarctic Marine Living Resources (AMLR) Program survey area in the northern Antarctic Peninsula. Inset (lower right corner): survey area relative to Antarctic and South American continents. Colored points represent stations sampled each year: red: 2013; green: 2014; blue: 2015; grey: 2016. See Table S1 for additional details

At each station, krill were collected using a $1.8 \mathrm{~m}$ Isaacs-Kidd mid-water trawl (IKMT) with a $505 \mu \mathrm{m}$ mesh plankton net. Station and tow data can be found in Table S1. More than $59 \%$ of all tows occurred after sunset. Krill larvae exhibit reverse diel migration and tend to be associated with the surface (especially the undersides of ice floes) during the day and the water column at night (Meyer et al. 2017), while post-larval krill are closer to the surface at night (Bernard et al. 2018). Tows were oblique to $170 \mathrm{~m}$ or within $10 \mathrm{~m}$ of the bottom in shallower areas. Zooplankton were enumerated and identified to species. For tows with fewer than 100 krill, all krill were measured for standard length (Mauchline 1980) and sex and maturity stages were determined (Makarov \& Denys 1981). For tows with more than 100 adult krill or krill larvae, a random subsample of 100-200 krill was selected by dipping a $1000 \mathrm{ml}$ beaker into a well-mixed sample of krill suspended in a known volume of ambient water. Krill were measured, sexed, and staged for maturity. Larvae were counted and identified to stage (usually furcilia III-VI) but were not measured for length. Krill that had been measured and sexed were immediately frozen at $-20^{\circ} \mathrm{C}$ for lipid and stable isotope analyses.

\subsection{Sea ice}

Monthly sea-ice concentration data for May-September of each year were obtained from the National Snow and Ice Data Center (www.nsidc.org) using their monthly Special Sensor Microwave/Imager (SSM/I) imagery (Figs. S1-S4 in Supplement 2 at www.int-res. com/articles/suppl/m642p001_supp2.pdf; sea ice analysis, US National Ice Center, 2013-2016). The sea-ice area $\left(\mathrm{km}^{2}\right)$ of 15 and $50 \%$ ice concentration for each month was calculated for the area between $58^{\circ} \mathrm{S}$, $48^{\circ} \mathrm{W}$ and $68^{\circ} \mathrm{S}, 65^{\circ} \mathrm{W}$ to provide a general overview of seasonal sea-ice development each year (see Fig. 2).

Ice type and percent cover were visually estimated by examining the ice conditions in a $200 \mathrm{~m}$ arc around the stern of the ship during the approach to each station and during net sampling. We modified the standardized visual approach from the Scientific Committee on Antarctic Research Antarctic Sea Ice Processes and Climate Program (ASPeCT; Worby et al. 1999) to classify ice type as slush (frazil, shuga, and grease ice; less than $100 \mathrm{~mm}$ thick), thin (nilas, pancake, young grey, and young grey-white ice; 100-300 mm thick), first-year (thicker and more solid ice; 300-1200 mm), and multi-year (more solid; any 


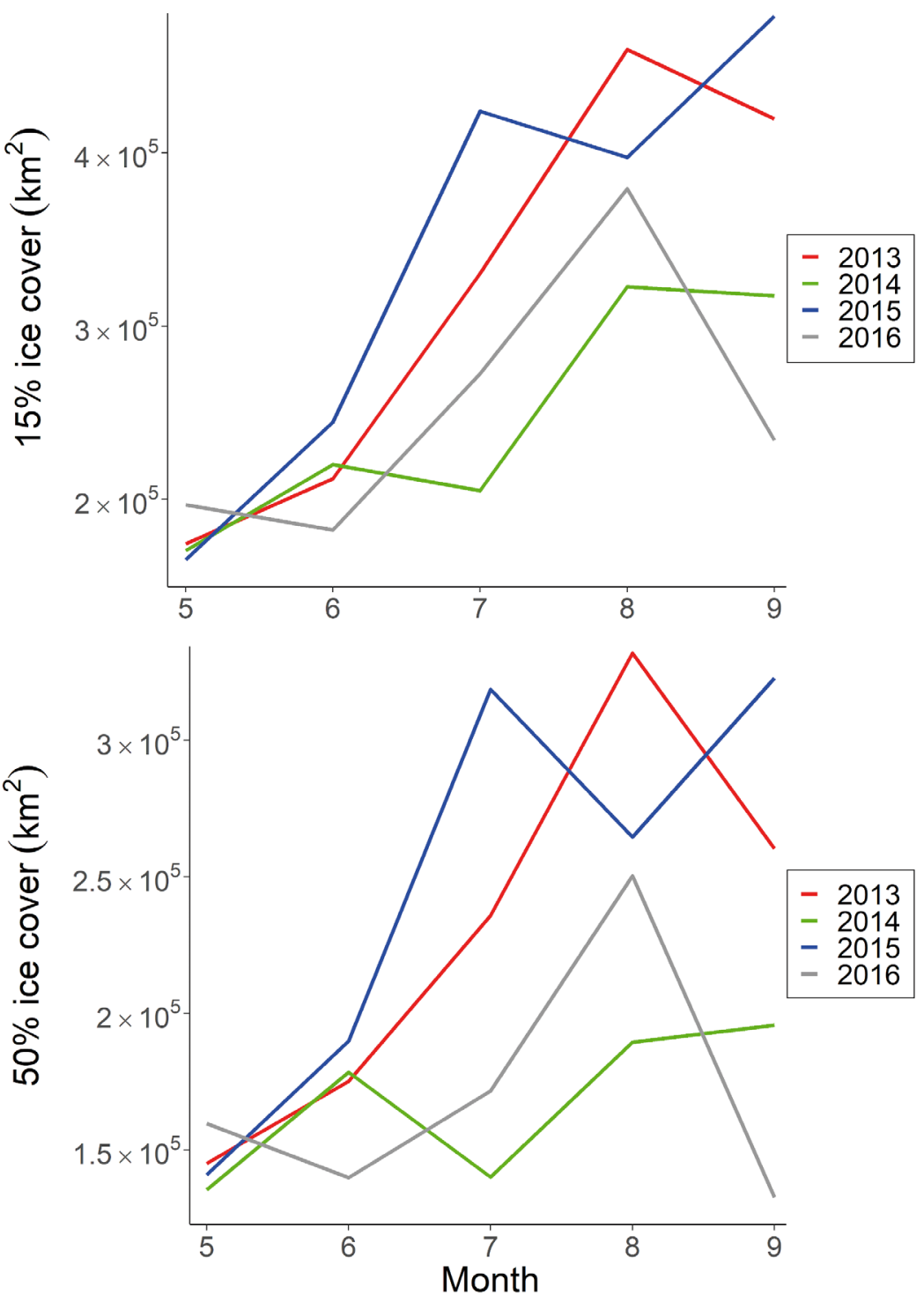

Fig. 2. Progression of coverage by (a) $15 \%$ and (b) $50 \%$ ice concentration from May (Month 5) through September (Month 9) each year. Ice cover was calculated for the area between $58^{\circ} \mathrm{S}, 48^{\circ} \mathrm{W}$ and $68^{\circ} \mathrm{S}, 65^{\circ} \mathrm{W}$. Note different $y$-axis scales extracted (Folch et al. 1957, Budge et al. 2006). Larvae (furcilia IV-VI) were not measured and were pooled by station to achieve a mass suitable for lipid extraction (usually 0.5-2.0 g). Lipid was extracted using a 2:1 chloroform/methanol solution with $0.01 \%$ butylated hydroxytoluene (BHT) as a preservative. Lipid dissolved in chloroform was dried using anhydrous sodium sulfate, and the chloroform solvent was evaporated under nitrogen. Lipid was weighed to the nearest $0.001 \mathrm{~g}$ to determine percent lipid in each sample.

Triacylglycerols were transesterified using a sulfuric acid catalyst (Hilditch \& Williams 1964), and the resulting fatty acid methyl ester (FAME) samples were extracted in hexane and dried over anhydrous sodium sulfate, and the hexane solvent evaporated under nitrogen. Hexane was added back to a concentration of 50 mg FAME $\mathrm{ml}^{-1}$ for gas chromatography analysis.

FAME samples were analyzed at NOAA's Southwest Fisheries Science Center (SWFSC) on a Perkin-Elmer Clarus 500 capillary gas chromatograph with a flame ionization detector (GC-FID) using a fused silica column coated with $50 \%$ cyanopropyl methylpolysiloxane (30 $\mathrm{m}, 0.25 \mathrm{~mm}$ internal diameter, $0.25 \mu \mathrm{m}$ film thickness, DB-23; Agilent Technologies), and using the oven program described in Appendix 7 of Budge et al. (2006). Fatty acids were identified by comparing sample peaks to standard peaks (Nu-Chek Prep) and area percent of peaks were determined using Total Chrom software (v.6.2.3; Perkin Elmer).

\subsection{Stable isotope analysis}

terized the percent ice cover as $0 \%$ (open water) 1-25, 26-50, 51-75, and 76-100\%. In general, firstyear and multi-year ice floes were most complex, especially when ice cover was greater than $50 \%$.

\subsection{Lipid analysis}

Frozen krill were processed for lipids at sea within $24 \mathrm{~h}$ of freezing (all diet indicators are provided in Table S2 in Supplement 1). Lipids from $1.5 \mathrm{~g}$ aliquots of homogenized adults of the same size and sex were
The same samples used for lipid analysis were also used for bulk stable isotope analysis. The lipid-free krill samples left over from lipid extraction were placed in glass vials and freeze-dried for $14-16 \mathrm{~h}$ in a VirTis Benchtop K Lyophilizer (SP Scientific). Dried samples were pulverized and 0.8-1.2 mg aliquots were placed into tin capsules and analyzed for $\delta^{13} \mathrm{C}$ and $\delta^{15} \mathrm{~N}$ isotopes at the University of California Davis Stable Isotope Facility using a PDZ Europa ANCA-GSL elemental analyzer interfaced to a PDZ Europa 20- 
20 isotope ratio mass spectrometer (Sercon). Isotopic values are reported as ratios of heavy to light isotopes $\left(\delta^{15} \mathrm{~N}\right.$ and $\left.\delta^{13} \mathrm{C}\right)$ in parts per thousand (\%o) compared to standards (atmospheric $\mathrm{N}_{2}$ and carbon in PeeDee limestone). Because the lipid extraction process can skew $\delta^{15} \mathrm{~N}$ values, the $\delta^{15} \mathrm{~N}$ values of lipid-extracted samples were adjusted using correction factors derived from whole-animal samples analyzed at the same facility. Correction factors were determined separately for post-larvae and larvae by calculating the difference between the mean $\delta^{15} \mathrm{~N}$ values of lipidextracted and whole-animal samples and adjusting the values of the lipid-extracted samples in the direction indicated by the whole-animal samples. Post-larval values were adjusted by $-0.76 \%$ and larval values were adjusted by $0.45 \%$. Because these values are small compared to an entire trophic shift of 2-5\% (Stowasser et al. 2012), and because we only compared annual diets within life stages, these adjustments did not affect the interpretation of our results.

Because we did not collect water-column POM or sea-ice biota for fatty acid or stable isotope analyses, we analyzed a subset of krill FAME samples from each year for compound-specific $\delta^{13} \mathrm{C}$ analysis to determine whether annual shifts in diet indicators resulted from annual differences in the carbon signatures of primary producers. To the maximum extent possible, samples from each year included krill collected in open water as well as all ice types. FAME samples $(\mathrm{n}=16)$ were analyzed at the University of California Davis Stable Isotope Facility using a Thermo GC-C-IRMS composed of a trace GC Ultra gas chromatograph (Thermo Electron Corp) coupled to a Delta V Advantage isotope ratio mass spectrometer through a GC/C-III interface (Thermo Electron Corp) (https://stableisotopefacility.ucdavis.edu/compoundspecific.html). The internal fatty acid standard 19:0 was added to all samples prior to analysis. We used compound-specific stable isotope analyses of the diatom marker 16:1n7 and the flagellate marker $18: 4 n-3$ to evaluate annual differences in the base of the food web at the time scale relevant to our sampling; these fatty acids are typically incorporated into storage lipids and are likely to more closely reflect the conditions in which krill were feeding during our survey (Kohlbach et al. 2017).

\subsection{Data analysis}

To determine abundance and recruitment strength, vertically integrated krill abundance at each station (no. $\mathrm{m}^{-2}$ ) was determined by dividing the total number of krill in a sample by the volume of seawater filtered (determined by a calibrated flow meter mounted on the net frame, Model 2030R; General Oceanics) and multiplying by the depth of the tow. Because krill are patchy in space, abundance data were $\ln (x+1)$ transformed to account for patchiness and to normalize the data for statistical analyses.

Population length density of krill across the survey area was determined using CMIX (de la Mare 1994), which accounts for both the probability of a zero haul and the patchiness of krill using a negative binomial distribution. From the population length density, we calculated the proportional density of krill less than $30 \mathrm{~mm}$ as a function of the total density of krill of all length classes each year, and used this as a measure of relative recruitment (Reiss 2008).

In total, 65 fatty acids were identified in the samples, accounting for $98-100 \%$ of all fatty acids present. Fatty acid proportions were normalized for each sample to exclude solvent and preservative peaks. We calculated a diatom index (DI) (16:1n-7/ 18:4n-3) to infer increased consumption of diatoms over flagellates (Stübing \& Hagen 2003, Stübing et al. 2003) as well as increased feeding in ice over open water (Garrison \& Close 1993, Garrison et al. 1993). We also calculated a carnivory index (CI) $(18: 1 n-9 / 18: 1 n-7)$ to infer increased consumption of heterotrophic over autotrophic resources (Stübing et al. 2003). The fatty acid 18:1n-9 primarily reflects marine animal lipids, while $18: 1 \mathrm{n}-7$ is most likely the result of chain elongation of $16: 1 \mathrm{n}-7$ and reflects marine algae (Falk-Petersen et al. 2000). Prior to statistical analyses, percent lipid data were arcsine-square-root transformed and fatty acid ratio data were log transformed to approximate normal distributions and facilitate inferences from statistical tests. We considered samples with lipid content greater than $50 \%$ as outliers and eliminated them from analysis. We performed 1-way ANOVAs to evaluate annual differences in diet indicators among years and Tukey's HSD for multiple comparisons with confidence levels of $95 \%$ when appropriate. We performed 2-way ANOVAs to evaluate annual differences in environmental variables and krill abundances among sampling sectors and years. All statistical tests were performed in R, version 3.6.0 (R Core Team 2019). Graphics were created using the $\mathrm{R}$ packages 'ggplot2' (Wickham 2016) and 'Lattice' (Sarkar 2008).

We performed a principal component analysis (PCA) to characterize a multi-dimensional habitat at 
each sampling station using percent ice cover, chl $a$, and temperature in the UML. We then used linear regressions to identify relationships between each diet indicator $\left(\delta^{13} \mathrm{C}, \delta^{15} \mathrm{~N}\right.$, lipid content, DI, and $\left.\mathrm{CI}\right)$ for each stage (post-larvae or larvae) against the PCA scores. Stage was coded as a sum contrast, and the regression models were weighted by the abundance of krill at each station. Weights were determined for each life stage at each station by calculating the number of standard deviations each station's abundance was from the mean annual abundance of each stage, and then scaling weights from 0 to 1 .

\section{RESULTS}

\subsection{Annual sea ice coverage}

The areal extent of sea ice covering the northern Antarctic Peninsula varied by year (Fig. 2a,b). During sampling in August, sea-ice coverage was highest in 2013, followed by 2015 and 2016. August sea-ice coverage was lowest in 2014. In September, sea-ice coverage was highest in 2015, followed by 2013 and 2014. September sea-ice coverage was lowest in 2016.

In 2013, we observed the highest percentage of stations with $76-100 \%$ ice cover in all sectors (Table 1). In 2014, we observed the highest percentage of open water stations among all sectors and years, except for the WA. In 2015, the highest percentages of open water stations occurred in the EI and JI sectors, while the highest percentages of stations with $76-100 \%$ ice cover occurred in the SA and WA. In 2016, we observed the highest percentages of $76-100 \%$ ice cover in the SA and JI sectors, but clear patterns in ice cover were not evident in the EI and WA sectors.

\subsection{Annual variation in environmental variables and krill abundance among sampling sectors}

Chl a differed significantly among years and sectors, with a significant interaction (Table 2), indicating that the variability in our survey area confounded the main effects of year and sector on chl $a$. In general, chl a was higher in 2013 and 2014 than in 2015 and 2016, and was higher in the EI and WA sectors each year than in the JI and SA sectors (Table 1). While average temperature in the UML differed significantly among years and sectors (Table 2), the range of temperatures was small. The minimum mean temperature observed across all years was $-1.84^{\circ} \mathrm{C}$ in the JI sector during 2013 and the maximum was $-1.66^{\circ} \mathrm{C}$ in the EI sector in 2016 (Table 1).

Post-larval abundance differed among sectors but not among years (Table 2, Fig. 3a). Abundances were highest in the SA sector every year (Tukey's HSD, $\mathrm{p}<0.001$ ), followed by the JI sector (Table 1,

Table 1. Mean ( \pm SD) chl $a$, water temperature (temp.), and Antarctic krill post-larval and larval abundance (abund.) for each sampling sector and each year. Percent ice cover categories are the percent of stations sampled each year in each category, regardless of whether samples were collected for diet analyses. AMLR: Antarctic Marine Living Resources

\begin{tabular}{|c|c|c|c|c|c|c|c|c|c|c|}
\hline AMLR area & Year & $\begin{array}{l}\text { Mean integrated } \\
\text { chl } a(100 \mathrm{~m})\end{array}$ & $\begin{array}{l}\text { Water } \\
\text { temp. }\left({ }^{\circ} \mathrm{C}\right)\end{array}$ & $\overline{0}$ & $\begin{array}{l}\text { Ice } \mathrm{c} \\
1-25\end{array}$ & $\begin{array}{r}\text { over }(\% \\
26-50\end{array}$ & $\begin{array}{l}\text { station } \\
51-75\end{array}$ & $76-100$ & $\begin{array}{c}\text { Post-larvae } \\
\text { abund. (no. } \mathrm{m}^{-2} \text { ) }\end{array}$ & $\begin{array}{c}\text { Larvae } \\
\text { abund. (no. } \mathrm{m}^{-2} \text { ) }\end{array}$ \\
\hline $\begin{array}{l}\text { Elephant } \\
\text { Island (EI) }\end{array}$ & $\begin{array}{l}2013 \\
2014 \\
2015 \\
2016\end{array}$ & $\begin{array}{l}16.49 \pm 6.47 \\
17.24 \pm 8.09 \\
15.69 \pm 6.96 \\
15.38 \pm 5.08\end{array}$ & $\begin{array}{r}-1.75 \pm 0.10 \\
-1.7 \pm 0.14 \\
-1.71 \pm 0.13 \\
-1.66 \pm 0.21\end{array}$ & $\begin{array}{c}6 \\
38 \\
49 \\
17\end{array}$ & $\begin{array}{l}35 \\
23 \\
11 \\
17\end{array}$ & $\begin{array}{l}12 \\
16 \\
13 \\
24\end{array}$ & $\begin{array}{c}8 \\
16 \\
11 \\
21\end{array}$ & $\begin{array}{c}39 \\
7 \\
16 \\
21\end{array}$ & $\begin{array}{c}1.31 \pm 4.46 \\
12.82 \pm 54.25 \\
2.91 \pm 7.32 \\
6.39 \pm 23.76\end{array}$ & $\begin{array}{c}2.26 \pm 5.29 \\
17.2 \pm 34.15 \\
356.08 \pm 868.27 \\
129.27 \pm 239.99\end{array}$ \\
\hline $\begin{array}{l}\text { Joinville } \\
\text { Island (JI) }\end{array}$ & $\begin{array}{l}2013 \\
2014 \\
2015 \\
2016\end{array}$ & $\begin{array}{r}13.97 \pm 1.02 \\
9.89 \pm 5.62 \\
4.25 \pm 2.06 \\
8.69 \pm 0.73\end{array}$ & $\begin{array}{l}-1.84 \pm 0.01 \\
-1.75 \pm 0.1 \\
-1.77 \pm 0.1 \\
-1.74 \pm 0.07\end{array}$ & $\begin{array}{c}0 \\
48 \\
39 \\
0\end{array}$ & $\begin{array}{c}0 \\
17 \\
22 \\
0\end{array}$ & $\begin{array}{c}0 \\
22 \\
6 \\
0\end{array}$ & $\begin{array}{c}0 \\
9 \\
11 \\
33\end{array}$ & $\begin{array}{c}100 \\
4 \\
22 \\
67\end{array}$ & $\begin{aligned} 1.95 & \pm 2.75 \\
31.33 & \pm 54.03 \\
171.68 & \pm 441.14 \\
15.22 & \pm 21.53\end{aligned}$ & $\begin{aligned} 0.13 & \pm 0.18 \\
18.74 & \pm 29.59 \\
219.74 & \pm 279.22 \\
17.92 & \pm 24.96\end{aligned}$ \\
\hline $\begin{array}{l}\text { South Area } \\
\text { (SA) }\end{array}$ & $\begin{array}{l}2013 \\
2014 \\
2015 \\
2016\end{array}$ & $\begin{array}{l}8.41 \pm 4.61 \\
9.45 \pm 2.97 \\
5.27 \pm 1.45 \\
5.80 \pm 2.17\end{array}$ & $\begin{array}{l}-1.74 \pm 0.12 \\
-1.77 \pm 0.07 \\
-1.79 \pm 0.07 \\
-1.73 \pm 0.16\end{array}$ & $\begin{array}{l}20 \\
36 \\
19 \\
20\end{array}$ & $\begin{array}{l}24 \\
16 \\
19 \\
10\end{array}$ & $\begin{array}{c}8 \\
20 \\
0 \\
7\end{array}$ & $\begin{array}{c}0 \\
28 \\
24 \\
18\end{array}$ & $\begin{array}{c}48 \\
0 \\
38 \\
45\end{array}$ & $\begin{aligned} 2856.29 & \pm 7052.66 \\
1278.38 & \pm 3343.55 \\
1182.14 & \pm 2422.87 \\
483.99 & \pm 707.35\end{aligned}$ & $\begin{aligned} 6.75 & \pm 11.71 \\
70.31 & \pm 192.81 \\
138.21 & \pm 227.64 \\
27.26 & \pm 37.77\end{aligned}$ \\
\hline $\begin{array}{l}\text { West Area } \\
\text { (WA) }\end{array}$ & $\begin{array}{l}2013 \\
2014 \\
2015 \\
2016\end{array}$ & $\begin{array}{r}15.54 \pm 4.07 \\
17.39 \pm 4.28 \\
9.0 \pm 2.33 \\
10.32 \pm 2.72\end{array}$ & $\begin{array}{l}-1.83 \pm 0.02 \\
-1.81 \pm 0.05 \\
-1.82 \pm 0.02 \\
-1.79 \pm 0.05\end{array}$ & $\begin{array}{c}10 \\
14 \\
0 \\
27\end{array}$ & $\begin{array}{c}14 \\
5 \\
10 \\
18\end{array}$ & $\begin{array}{l}10 \\
27 \\
32 \\
23\end{array}$ & $\begin{array}{l}14 \\
36 \\
16 \\
14\end{array}$ & $\begin{array}{l}52 \\
18 \\
42 \\
18\end{array}$ & $\begin{array}{l}118.4 \pm 456.73 \\
45.23 \pm 152.26 \\
17.97 \pm 60.95 \\
51.64 \pm 153.54\end{array}$ & $\begin{aligned} 5.29 & \pm 9.35 \\
23.57 & \pm 55.39 \\
130.38 & \pm 393.07 \\
79.52 & \pm 249.19\end{aligned}$ \\
\hline
\end{tabular}


Fig. 3a). Larval abundance differed among years but not among sectors, with a significant interaction (Table 2, Fig. 3b), indicating that the variability in our survey area confounded the main effects of year and sector on larval abundance. Abundances in all sectors were lowest in 2013 and highest in 2015 (Table 1, Fig. 3b).

\subsection{Compound-specific stable isotope analysis}

Compound-specific $\delta^{13} \mathrm{C}$ in $16: 1 \mathrm{n}-7$ and $18: 4 \mathrm{n}-3 \mathrm{did}$ not vary among years $\left(16: 1 \mathrm{n}-7: F_{1,14}=1.99, \mathrm{p}=0.18\right.$; $18: 4 \mathrm{n}-3: F_{1,14}=3.25, \mathrm{p}=0.09$ ), suggesting that annual variation in diet was the result of differences in prey consumed each year.

\subsection{Annual variation in diet indicators}

We observed substantial annual variation in the diets of krill within each life stage (Tables $2 \& 3$ ). Among post-larvae, lipid content was lowest in 2014. The DI was highest in 2016 (Tukey's HSD, $\mathrm{p}<0.001)$, and was lower in 2014 than in 2015 (Tukey's HSD, p < 0.05). The CI was highest in 2013 (Tukey's HSD, p < 0.05), and was lower in 2015 than in 2014 and 2016 (Tukey's HSD, p < 0.05 for both years). Values of $\delta^{15} \mathrm{~N}$ were higher in 2016 than in 2013 (Tukey's HSD, p < 0.05) and 2015 (Tukey's HSD, p < 0.001). Values of $\delta^{13} \mathrm{C}$ were not different between 2013 and 2015 (more depleted) and between 2014 and 2016 (more enriched), but were different between the more depleted and more enriched years (Tukey's HSD, $p<0.01$ for all between-year comparisons).

Among larvae, lipid content was highest in 2013 (Tables $2 \& 3$ ). The DI was highest in 2013, while the CI was higher in 2014 than in 2015 and 2016 (Tukey's HSD, $\mathrm{p}<0.001$ for both years). Values of $\delta^{15} \mathrm{~N}$ were lower in 2015 than in 2014 (Tukey's HSD, p < 0.001) and 2016 (Tukey's HSD, $\mathrm{p}<0.01$ ). Values of $\delta^{13} \mathrm{C}$ were lower in 2014 than in 2015 (Tukey's HSD, p < 0.05) and 2016 (Tukey's HSD, p < 0.001), and higher in 2016 than in 2015 (Tukey's HSD, $\mathrm{p}<0.05$ ).

\subsection{Habitat characterization using PCA}

The first principal component (PC1) discriminated between habitats in which percent ice cover and temperature in the UML trended in opposite directions with an increasing score (e.g. less ice and
Table 2. Results of 2-way ANOVAs (chl $a$, upper mixed layer [UML] temperature, and abundances of Antarctic krill postlarvae and larvae against sampling sector and year), and 1way ANOVAs (diet indicators against year). CI: carnivory index; DI: diatom index

\begin{tabular}{|c|c|c|c|c|c|}
\hline & $\mathrm{df}$ & SS & MS & $F$ & $\mathrm{p}$ \\
\hline \multicolumn{6}{|l|}{ Chl a } \\
\hline Sector & 3 & 5970 & 1989.9 & 72.859 & $<0.001$ \\
\hline Year & 3 & 1164 & 388 & 14.207 & $<0.001$ \\
\hline Sector $\times$ year & 9 & 556 & 61.8 & 2.264 & 0.018 \\
\hline Residuals & 366 & 9996 & 27.3 & & \\
\hline \multicolumn{6}{|c|}{ UML temperature } \\
\hline Sector & 3 & 0.472 & 0.157 & 11.682 & $<0.001$ \\
\hline Year & 3 & 0.179 & 0.05961 & 4.426 & 0.00452 \\
\hline Sector $\times$ year & 9 & 0.082 & 0.00915 & 0.679 & 0.72785 \\
\hline Residuals & 357 & 4.808 & 0.01347 & & \\
\hline \multicolumn{6}{|c|}{ Post-larvae abundance } \\
\hline Sector & 3 & 907.8 & 302.61 & 75.28 & $<0.001$ \\
\hline Year & 3 & 13 & 4.33 & 1.076 & 0.359 \\
\hline Sector $\times$ year & 9 & 32.6 & 3.62 & 0.901 & 0.525 \\
\hline Residuals & 378 & 1519.4 & 4.02 & & \\
\hline \multicolumn{6}{|c|}{ Larvae abundance } \\
\hline Sector & 3 & 19.1 & 6.36 & 2.187 & 0.089 \\
\hline Year & 3 & 426.2 & 142.08 & 48.87 & $<0.001$ \\
\hline Sector $\times$ year & 9 & 66.4 & 7.37 & 2.537 & 0.0078 \\
\hline Residuals & 378 & 1098.9 & 2.91 & & \\
\hline \multicolumn{6}{|c|}{ Post-larvae lipid } \\
\hline Year & 3 & 0.3125 & 0.10416 & 10.88 & $<0.001$ \\
\hline Residuals & 95 & 0.9092 & 0.00957 & & \\
\hline \multicolumn{6}{|c|}{ Post-larvae $\delta^{15} \mathrm{~N}$} \\
\hline Year & 3 & 3.325 & 1.1084 & 7.306 & $<0.001$ \\
\hline Residuals & 95 & 14.412 & 0.1517 & & \\
\hline \multicolumn{6}{|c|}{ Post-larvae $\delta^{13} \mathrm{C}$} \\
\hline Year & 3 & 55.45 & 18.484 & 20.01 & $<0.001$ \\
\hline Residuals & 95 & 87.77 & 0.924 & & \\
\hline \multicolumn{6}{|c|}{ Post-larvae DI } \\
\hline Year & 3 & 2.212 & 0.7374 & 33.45 & $<0.001$ \\
\hline Residuals & 95 & 2.095 & 0.022 & & \\
\hline \multicolumn{6}{|l|}{ Post-larvae CI } \\
\hline Year & 3 & 0.6548 & 0.21825 & 13.79 & $<0.001$ \\
\hline Residuals & 95 & 1.5031 & 0.01582 & & \\
\hline \multicolumn{6}{|l|}{ Larvae lipid } \\
\hline Year & 3 & 0.0599 & 0.019968 & 8.295 & $<0.001$ \\
\hline Residuals & 40 & 0.09629 & 0.002407 & & \\
\hline \multicolumn{6}{|l|}{ Larvae $\delta^{15} \mathrm{~N}$} \\
\hline Year & 3 & 11.05 & 3.684 & 7.866 & $<0.001$ \\
\hline Residuals & 40 & 18.74 & 0.468 & & \\
\hline \multicolumn{6}{|l|}{ Larvae $\delta^{13} \mathrm{C}$} \\
\hline Year & 3 & 62.69 & 20.764 & 10.42 & $<0.001$ \\
\hline Residuals & 40 & 79.74 & 1.994 & & \\
\hline \multicolumn{6}{|l|}{ Larvae DI } \\
\hline Year & 3 & 0.5052 & 0.16841 & 6.98 & $<0.001$ \\
\hline Residuals & 40 & 0.9651 & 0.02413 & & \\
\hline \multicolumn{6}{|l|}{ Larvae CI } \\
\hline Year & 3 & 1.427 & 0.4758 & 16.26 & $<0.001$ \\
\hline Residuals & 40 & 1.171 & 0.0293 & & \\
\hline
\end{tabular}

warmer water with an increasing score; Fig. $4 \mathrm{a}-\mathrm{c}$ ) and explained $43.6 \%$ of the variance among all habitats at our sampling stations (Table 4). The sec- 
a

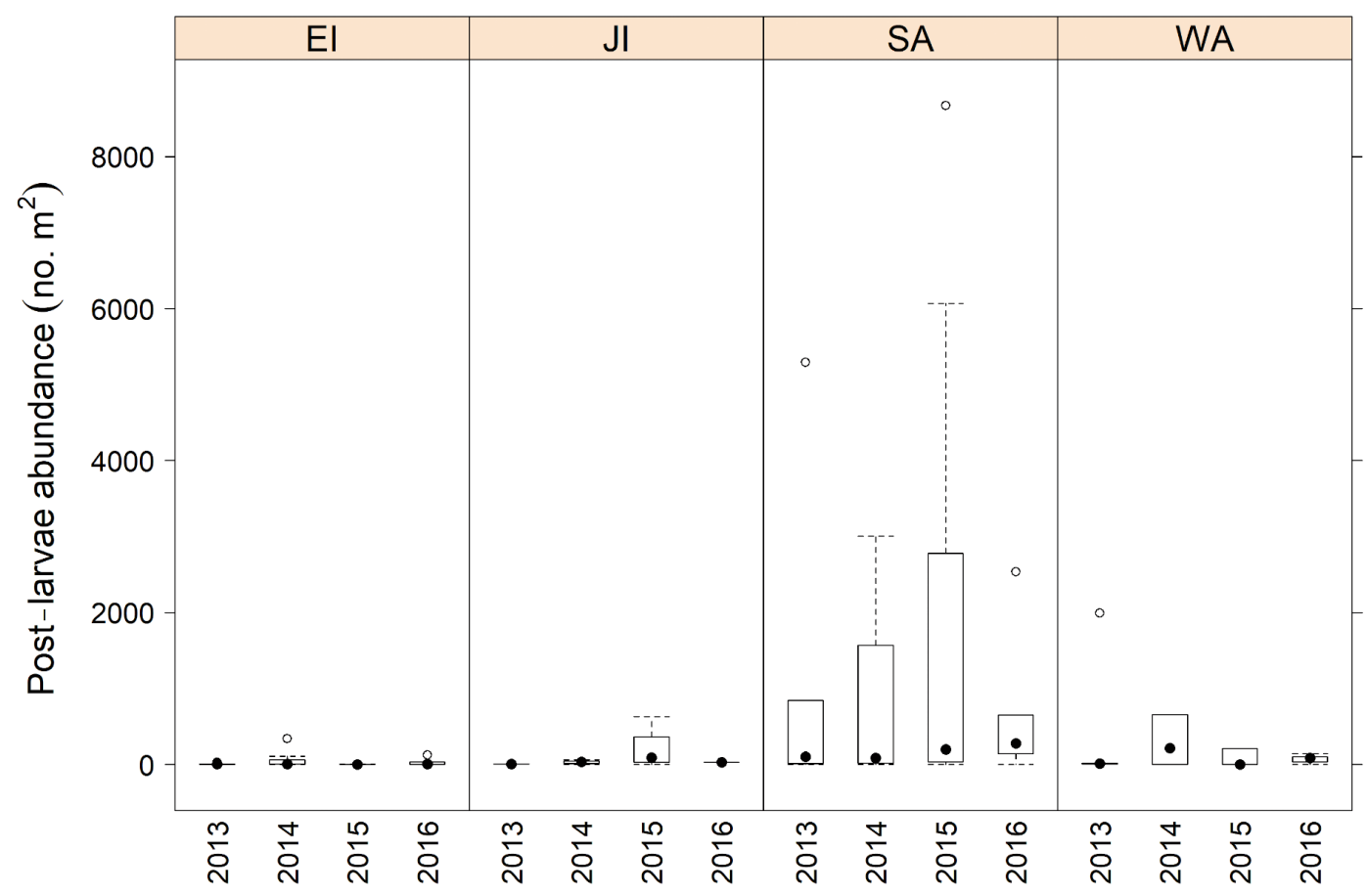

b

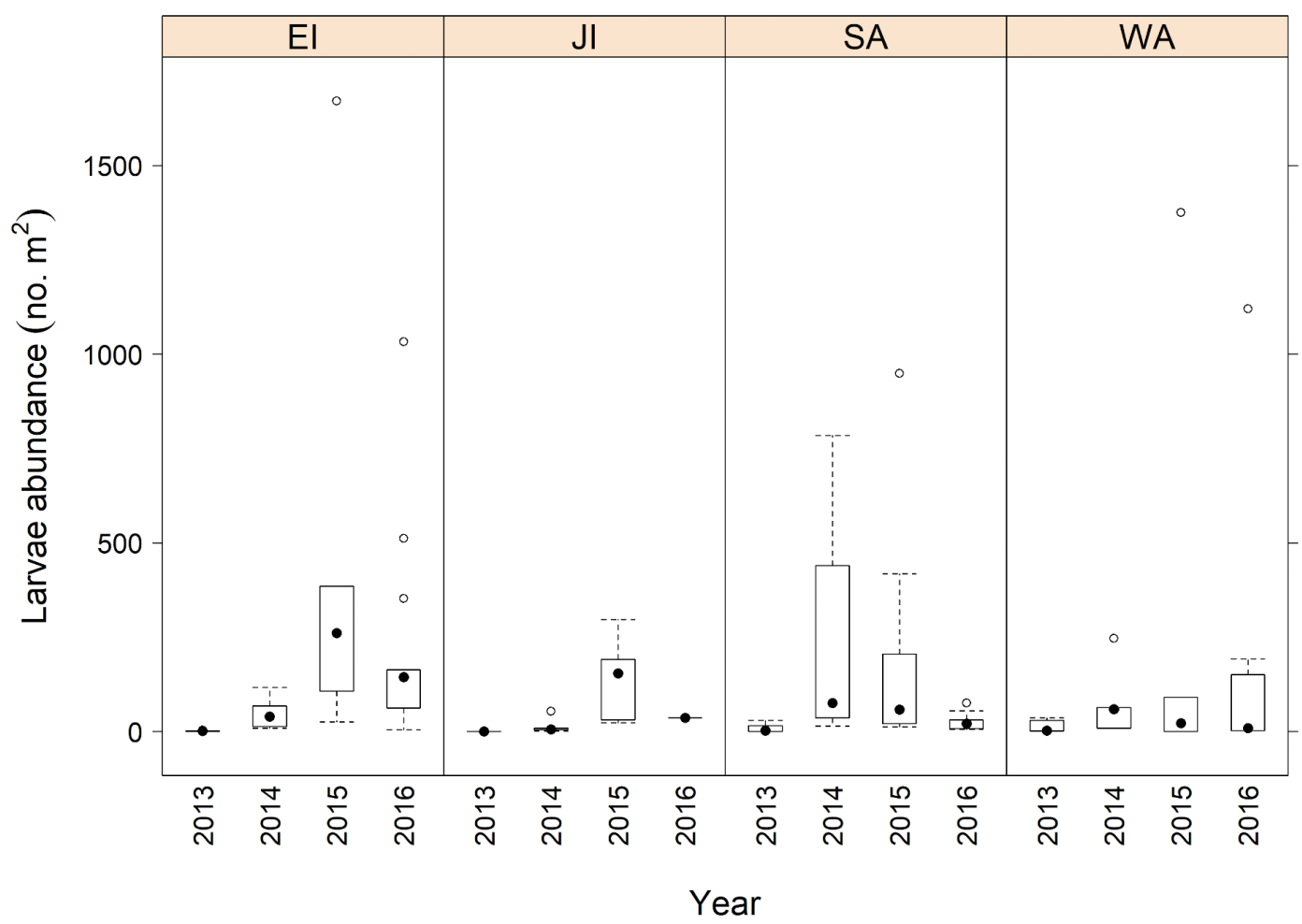

Fig. 3. Antarctic krill abundance by sampling sector (EI: Elephant Island; JI: Joinville Island; SA: south area; WA: west area) and year for (a) post-larvae and (b) larvae. Note different $y$-axis scales. Boxes: interquartile range of abundances; solid black circles: median abundances each year for each sector; whiskers: first and fourth quartiles of abundances; open circles: outliers 
Table 3. Mean ( \pm SD) Antarctic krill post-larvae length and diet indicators. Number of samples (n): number of stations included in the diet analyses each year. Larvae were not measured for length but were staged; all larvae were furcilia IV-VI. DI: diatom index (16:1n-7/18:4n-3); CI: carnivory index (18:1n-9/18:1n-7)

\begin{tabular}{|lcccccccc|}
\hline Krill stage & Year & $\mathrm{n}$ & Length $(\mathrm{mm})$ & Lipid (\%) & DI & CI & $\delta^{15} \mathrm{~N}$ & $\delta^{13} \mathrm{C}$ \\
\hline Post-larvae & 2013 & 30 & $36.0 \pm 6.2$ & $22.5 \pm 9.4$ & $1.6 \pm 0.2$ & $1.3 \pm 0.2$ & $4.2 \pm 0.3$ & $-25.4 \pm 0.8$ \\
& 2014 & 21 & $34.4 \pm 8.7$ & $14.8 \pm 6.4$ & $1.5 \pm 0.2$ & $1.2 \pm 0.1$ & $4.2 \pm 0.3$ & $-24.5 \pm 1.2$ \\
& 2015 & 23 & $36.4 \pm 4.7$ & $24.7 \pm 5.7$ & $1.7 \pm 0.1$ & $1.1 \pm 0.1$ & $4.0 \pm 0.4$ & $-25.7 \pm 0.6$ \\
& 2016 & 25 & $43.4 \pm 5.6$ & $27.1 \pm 9.0$ & $2.3 \pm 0.5$ & $1.2 \pm 0.2$ & $4.5 \pm 0.5$ & $-23.8 \pm 1.2$ \\
Larvae & 2013 & 2 & NA & $14.7 \pm 0.6$ & $2.1 \pm 0.3$ & $0.6 \pm 0.1$ & $5.1 \pm 0.2$ & $-21.9 \pm 0.3$ \\
& 2014 & 9 & NA & $4.3 \pm 1.8$ & $1.3 \pm 0.3$ & $0.8 \pm 0.2$ & $6.0 \pm 0.3$ & $-23.8 \pm 1.9$ \\
& 2015 & 15 & NA & $6.7 \pm 3.3$ & $1.5 \pm 0.2$ & $0.5 \pm 0.1$ & $4.7 \pm 0.5$ & $-22.2 \pm 0.8$ \\
& 2016 & 18 & NA & $6.2 \pm 1.3$ & $1.3 \pm 0.2$ & $0.6 \pm 0.1$ & $5.7 \pm 0.9$ & $-20.7 \pm 1.6$ \\
\hline
\end{tabular}

ond PC (PC2) was primarily associated with chl a (with higher scores indicating less chl a) and explained $33.4 \%$ of the variance among habitats. The third PC (PC3) discriminated habitats in which percent ice cover and temperature in the UML trended in similar directions with an increasing score (e.g. more ice and warm water with an increasing score). PC3 explained $23 \%$ of the variance among habitats.

Among stations where post-larvae were collected, PC1 scores differed among years $\left(F_{3,95}=3.41\right.$, $\mathrm{p}<0.05)$; scores were higher in 2016 than in 2015 (Tukey's HSD, p < 0.05) and did not differ among other years (Fig. 5a). Among stations where larvae were collected, PC1 scores differed among years $\left(F_{3,40}=7.29, \mathrm{p}<0.001\right)$; scores were higher in 2014 than in 2015 (Tukey's HSD, p < 0.001) and 2016 (Tukey's HSD, p < 0.01) (Fig. 5b).

Among stations where post-larvae were collected, PC2 scores differed among years $\left(F_{3,95}=19.15\right.$, $\mathrm{p}<0.001$ ); PC2 scores were higher in 2015 and 2016 than in 2013 and 2014 (Tukey's HSD, p < 0.001 for all between-year comparisons) (Fig. 5a). Among stations where larvae were collected, PC2 scores did not differ significantly among years (Fig. 5b). Among stations where post-larvae and larvae were collected, PC3 scores did not differ significantly among years for either life stage (Fig. 5a,b).

Regression models indicated that krill stage was a significant predictor for each diet indicator $(\mathrm{p}<0.001$ for all indicators) (Table 5). PC1 and PC3 were not significantly correlated with any diet indicator ( $p>0.1$ for each indicator), but PC2 was significantly correlated with all diet indicators $(p<0.05)$ except the CI $(\mathrm{p}=0.31)$. In post-larvae, lipid content, $\delta^{15} \mathrm{~N}$, and the DI increased as PC2 increased (Fig. 6a-c). In larvae, only $\delta^{13} \mathrm{C}$ increased as PC2 increased (Fig. 6d).

\subsection{Annual recruitment success}

Proportional recruitments of cohorts produced in 2012-2015 (and sampled in winters 2013-2016) were respectively $0.20,0.14,0.47$, and 0.10 . In all winters, post-larvae dominated, and we observed mostly $33 \mathrm{~mm}$ krill in 2013 and 36-40 mm krill in 2014 (Fig. 7). While we observed a small recruitment pulse in winter 2014 (comprising low densities [ $<1$ ind. $\mathrm{m}^{-2}$ ] of $16-17$ and $22-25 \mathrm{~mm}$ animals), 30$35 \mathrm{~mm}$ krill dominated the population in 2015 (Fig. 7). Also in 2015, we caught relatively few krill larger than $40 \mathrm{~mm}$. In 2016, we observed a broader distribution of krill lengths, ranging from approximately 32-45 mm (Fig. 7). Thus, despite high abundances of krill larvae across all sectors in 2015, we did not observe any substantial recruitment events across our time series.

\section{DISCUSSION}

Over 4 consecutive years of winter studies around the northern Antarctic Peninsula, we found that krill in this area exhibited a high degree of dietary flexibility in response to varying environmental conditions. We considered 3 variables (percent ice cover, integrated water-column chl $a$, and water temperature in the UML) known to influence the physiology or diet of krill and linked to recruitment to explore which of these variables had the greatest effect on dietary differences among years. Our results showed that although larval krill around the northern Antarctic Peninsula exploit sea-ice resources when they are available, both life stages can persist regardless of sea ice, and sea ice was not a reliable predictor of diet. Additionally, we did not discern a simple relationship between winter sea ice and recruitment 


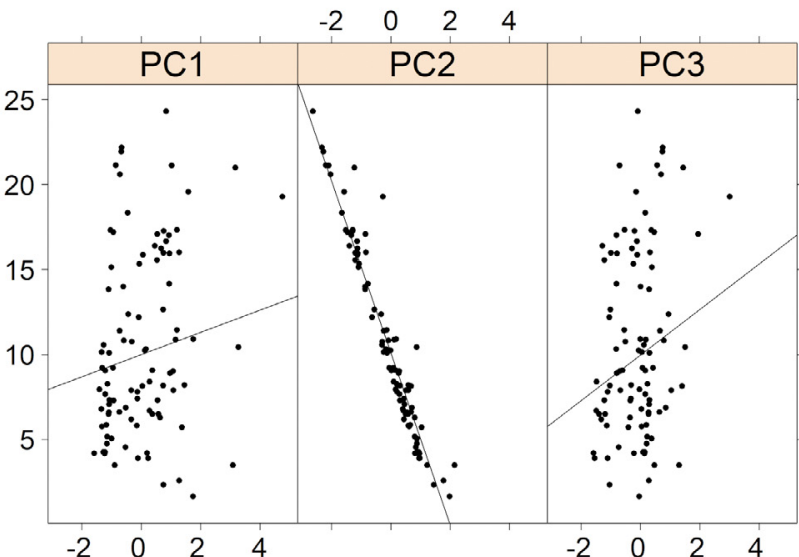

b
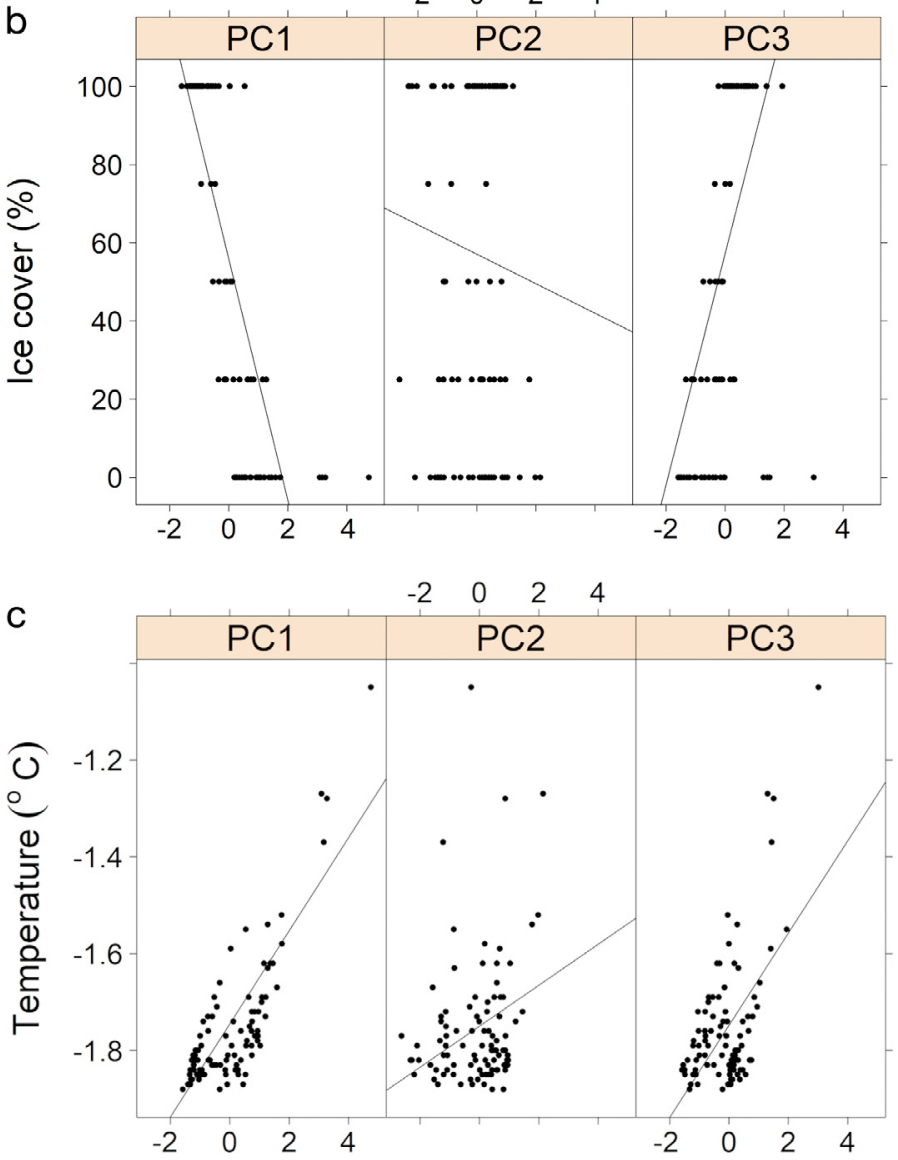

Fig. 4. Relationships between (a) mean integrated chl a $(100 \mathrm{~m}),(\mathrm{b})$ percent ice cover, and (c) upper mixed layer temperature and the first 3 principal component (PC) scores. Trendlines represent linear regressions

success the following year. These results suggest that projecting the impacts of changing environmental conditions on the future population dynamics of krill, based on simple or direct correlations between dietary proxies and physical habitat structure, may be more difficult than currently hypothesized.
Table 4. Principal component analysis results showing correlations of percent ice cover, chl $a$, and water temperature with the first $3 \mathrm{PCs}$

\begin{tabular}{|lrrc|}
\hline Variable & PC1 & PC2 & PC3 \\
\hline Ice cover $(\%)$ & -0.708 & 0.011 & 0.706 \\
Mean integrated chl a $(100 \mathrm{~m})$ & 0.182 & -0.963 & 0.197 \\
Water temperature $\left({ }^{\circ} \mathrm{C}\right)$ & 0.682 & 0.268 & 0.68 \\
Proportion of variance & 0.436 & 0.334 & 0.23 \\
\hline
\end{tabular}

\subsection{Environmental variables in relation to diet}

Among the environmental variables we considered in relation to diet, UML temperature had no significant effects on diet, and we will not discuss temperature further. Of the remaining 2 variables, winter sea-ice cover has long been considered the most important factor in successful growth, development, and recruitment of larvae (Quetin \& Ross 1991, Siegel \& Loeb 1995, Atkinson et al. 2004, Flores et al. 2012). Most winter studies indicate that ice that forms earlier in autumn and retreats in late winter or early spring constitutes favorable habitat for overwintering krill, particularly larvae (Quetin et al. 2007, Fritsen et al. 2008) because, compared to the water column, it may contain a concentrated source of food dominated by diatoms (Garrison \& Close 1993, Quetin et al. 2007).

Our observations showed that diet indicators in postlarvae each year were largely unrelated to annual sea-ice cover. The concentration of post-larvae in the southern parts of our survey area is an annual phenomenon that appears to be independent of ice cover or chl a concentration (Reiss et al. 2017), but some sea ice was usually present each year (Table 1). However, the diet indicators most closely associated with consumption of sea-ice resources did not follow patterns consistent with feeding in sea ice (Tables $2 \& 3$ ). Only $\delta^{13} \mathrm{C}$ changed in concert with annual sea-ice cover; values were enriched during low-ice years (2014 and 2016) and depleted during high-ice years (2013 and 2015). This relationship is the opposite of what we would expect if post-larvae had consumed sea-ice biota during autumn and early winter of high-ice years, and could be explained by feeding on benthic detritus during autumn and early winter of low-ice years (Kawaguchi et al. 1986, France 1995, Schmidt et al. 2014). A lack of relationships between winter sea-ice cover and the DI and CI may be because post-larvae reduce their feeding rate in winter and rely on lipid stores accumulated during summer and autumn (Meyer 2012), possibly obscuring dietary sig- 
a

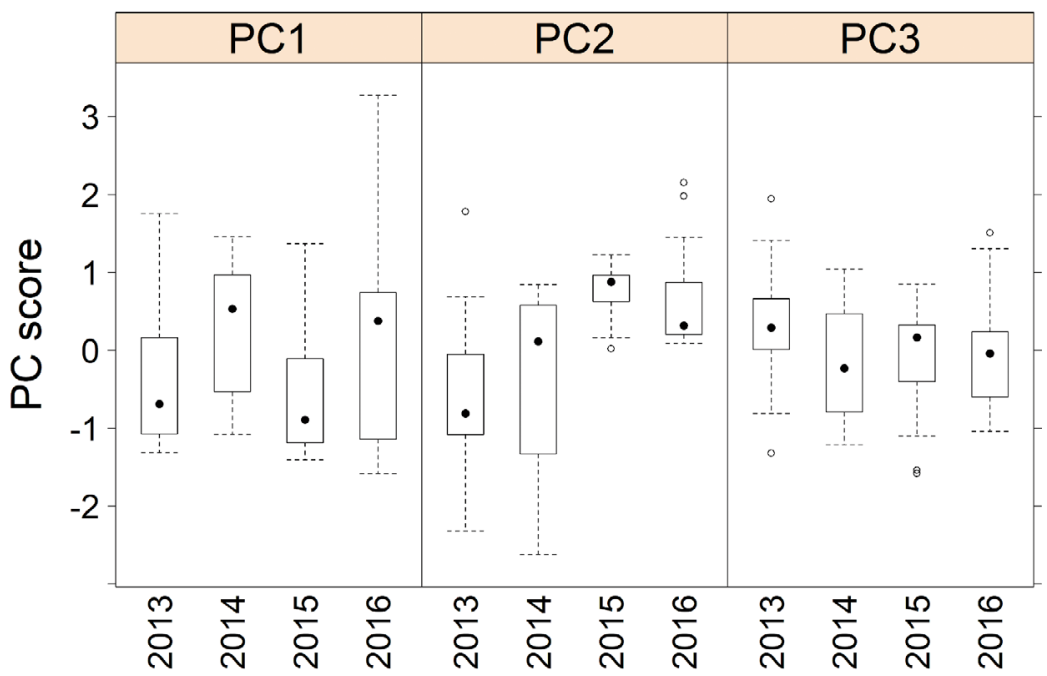

b

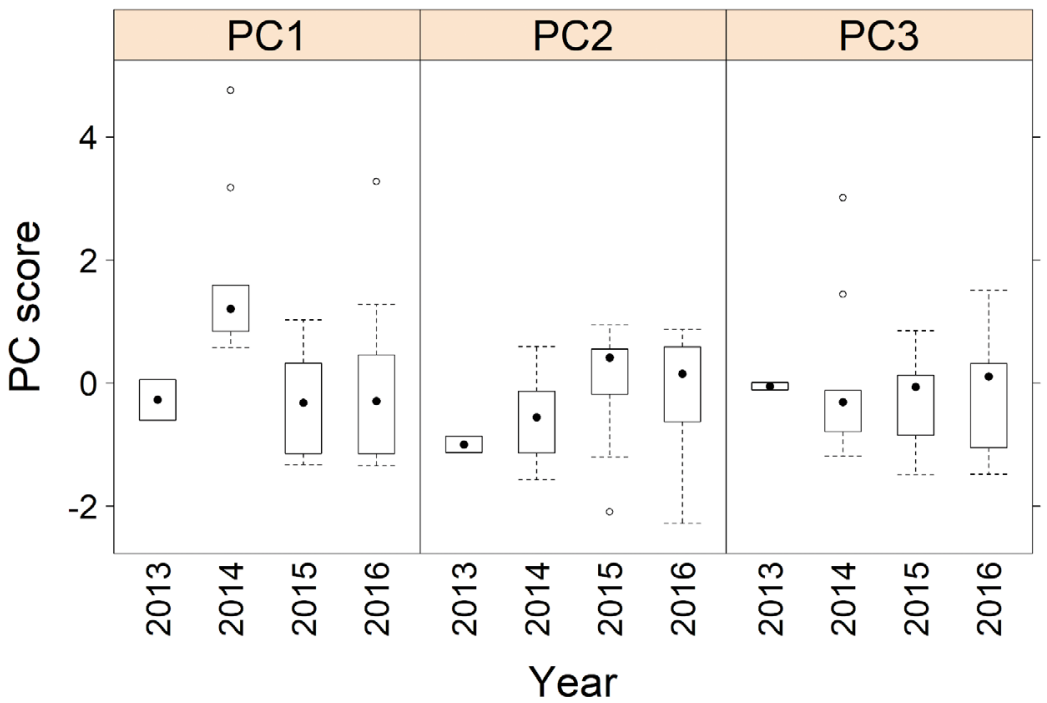

Fig. 5. Principal component (PC) scores by year in Antarctic krill (a) post-larvae and (b) larvae. Increasing PC1 scores are associated with less sea ice and warmer water. Increasing PC2 scores are associated with less chl $a$. Increasing PC3 scores are associated with more sea ice and warmer water. See Fig. 3 for boxplot parameters

Table 5. Rate estimates ( $p$-values in parentheses) from multiple linear regressions for each Antarctic krill diet indicator (with relevant transformations described in the text) on stage (post-larvae or larvae) and 3 PC scores. Stage was coded as a sum contrast, and models were weighted by the abundance of krill at each station. DI: diatom index; CI: carnivory index

\begin{tabular}{|lcccc|}
\hline Response variable & Stage & PC1 & PC2 & PC3 \\
\hline Lipid content $(\%)$ & $-0.12(<0.01)$ & $-0.30 \times 10^{-2}(0.56)$ & $0.04(<0.01)$ & $-0.01(0.47)$ \\
DI & $-0.11(<0.01)$ & $0.20 \times 10^{-2}(0.87)$ & $0.07(<0.01)$ & $0.01(0.61)$ \\
CI & $-0.36(<0.01)$ & $0.02(0.18)$ & $-0.02(0.31)$ & $0.01(0.50)$ \\
$\delta^{13} \mathrm{C}$ & $1.77(<0.01)$ & $-0.12(0.21)$ & $0.33(0.01)$ & $0.03(0.84)$ \\
$\delta^{15} \mathrm{~N}$ & $0.68(<0.01)$ & $0.03(0.46)$ & $0.11(0.02)$ & $0.03(0.6)$ \\
\hline
\end{tabular}

nals incorporated from feeding during winter (Stübing \& Hagen 2003). Alternatively, post-larvae may feed opportunistically during winter (Atkinson et al. 2002), suggesting that the lack of relationships we observed between sea-ice cover and the DI and CI may further indicate that post-larvae did not rely on sea-ice resources.

Our observations also showed that larvae are flexible in their dietary responses to dynamic environmental conditions, and can survive the winter by consuming a variety of resources depending on availability each year. Larvae must feed during winter to survive and maintain growth (Daly 1990, Quetin \& Ross 1991, Meyer et al. 2002), and larvae may gain more lipid feeding on ice diatoms than on phytoplankton or on mixed sea-ice biota (Stübing et al. 2003). Larvae feeding in SIMCOs may also have improved body condition and higher growth rates compared to those feeding in open water (Frazer et al. 2002b, Quetin et al. 2003). We found trends in the condition and diet of larvae that suggested they may have fed on sea-ice resources when sea ice was present, and also that the quality and abundance of the ice biota may have been influenced by the patterns of increase of sea-ice cover each year (as suggested by Lowe et al. 2012). We also found that during low-ice years when sea-ice resources may have been scarce, larvae were able to survive by consuming alternative resources, mostly in the water column.

Sea-ice cover was highest in 2013 and 2015 (Fig. 2a,b), but larvae were significantly more lipid-rich in 2013 (Tables 2 \& 3), suggesting that SIMCO biomass may have been higher in 2013 because ice cover grew steadily over autumn and winter with no midwinter decline. Ice retreat between July and August 2015 may have adversely affected available SIMCO biomass. Levels of $\delta^{15} \mathrm{~N}$ and $\delta^{13} \mathrm{C}$ in 
a

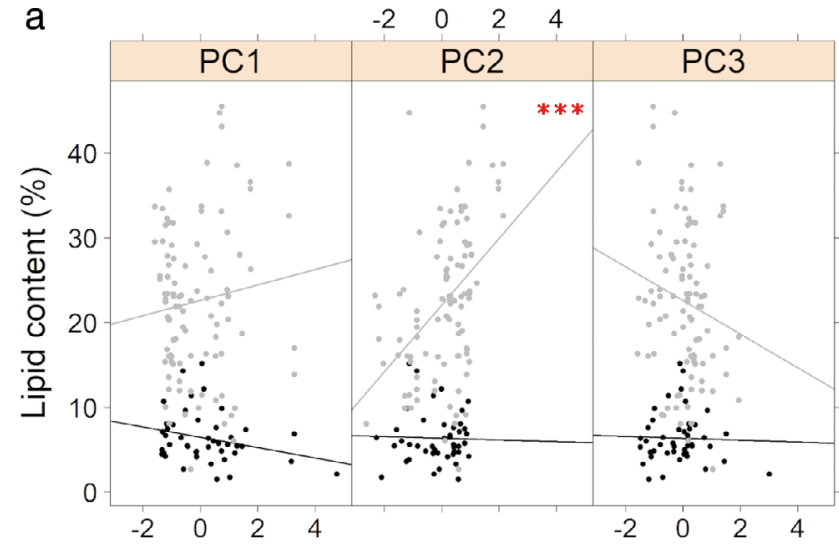

$\mathrm{b}$

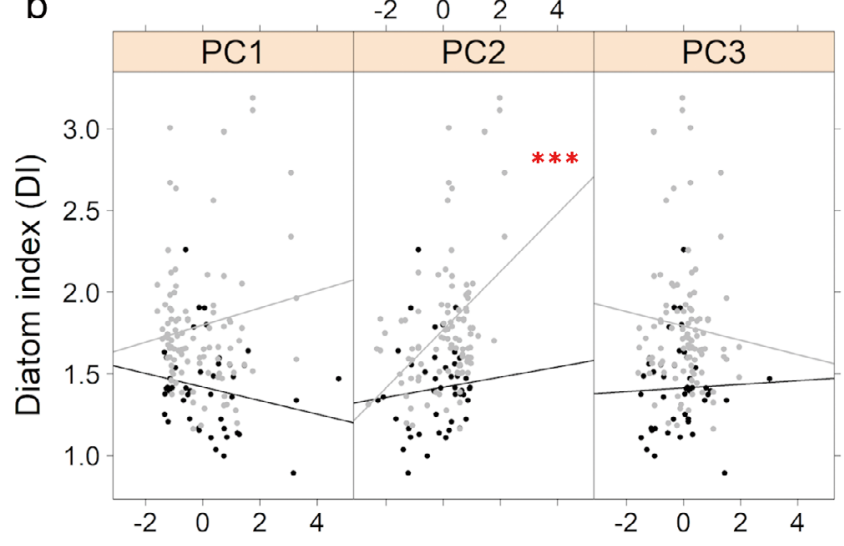

C

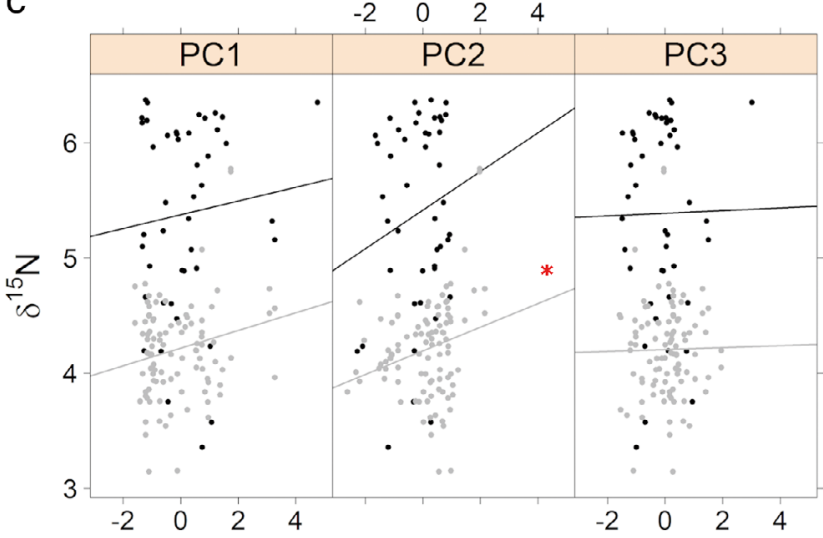

d

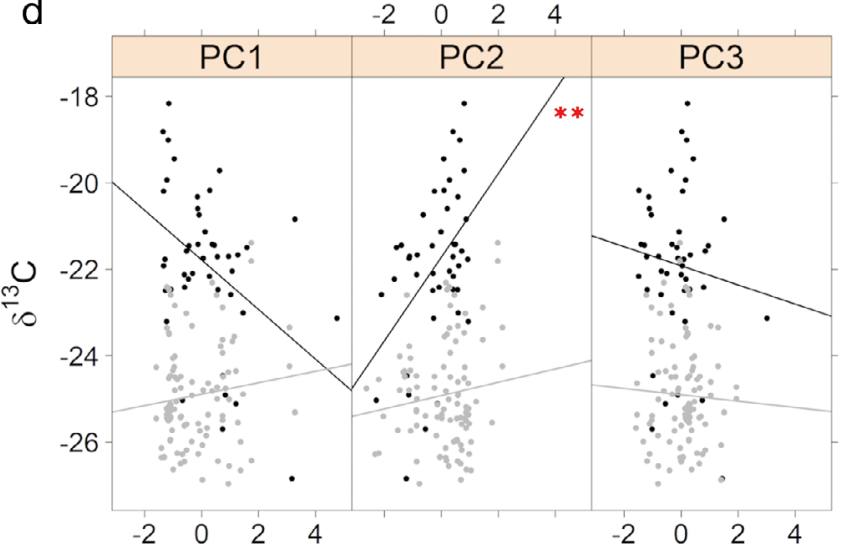

Fig. 6. Antarctic krill diet indicators by principal component (PC) scores for the first 3 PCs. CI not pictured (no significant relationships with PC scores). Grey points and lines: postlarvae; black points and lines: larvae. Increasing PC1 scores are associated with less sea ice and warmer water. Increasing PC2 scores are associated with less chl a. Increasing PC3 scores are associated with more sea ice and warmer water. Trendlines represent linear regressions. PC1 was not correlated with any diet indicators in post-larvae or larvae. In postlarvae, (a) lipid content $\left(F_{1,97}=20.98, \mathrm{p}<0.001\right)$, (b) diatom index $\left(F_{1,97}=21.69, \mathrm{p}<0.001\right)$, and $(\mathrm{c}) \delta^{15} \mathrm{~N}\left(F_{1,97}=6.09\right.$, $\mathrm{p}<0.05$ ) significantly increased with PC2. (d) In larvae, $\delta^{13} \mathrm{C}$ increased with PC2 $\left(F_{1,42}=11.37, \mathrm{p}<0.01\right) .{ }^{* * *} \mathrm{p}<0.001$;

$$
{ }^{* *} \mathrm{p}<0.01 ;{ }^{*} \mathrm{p}<0.05
$$

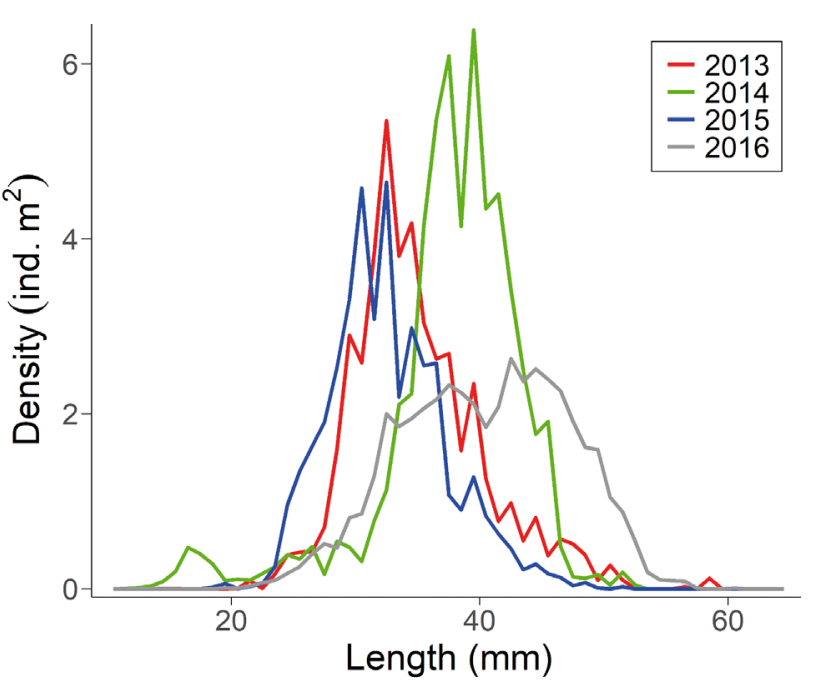

Fig. 7. Antarctic krill post-larvae length densities by year determined from net tows

larvae were similar between these years, which suggests that diets were comparable in autumn and early winter. Ice dynamics later in the winter of 2015 may have led to suboptimal SIMCO resources, resulting in lower lipid content of larvae, similar to levels observed in 2014 and 2016.

Ice cover in our survey area was lowest in 2014 and 2016, and ice advanced more slowly in these years, particularly during 2014 (Fig. 2a,b). In 2014, larvae were likely feeding on heterotrophic resources in the water column during autumn and early winter because sufficient sea-ice resources may not have been available, resulting in high values of $\delta^{15} \mathrm{~N}$ (Table 3). Low values of $\delta^{13} \mathrm{C}$ found in larvae during 2014 are also indicative of feeding in open water (Frazer 1996). Low lipid content, high $\delta^{15} \mathrm{~N}$, low DI, and high CI in larvae mostly likely reflect continued feeding on heterotrophic water column resources throughout winter 2014, since extensive sea ice failed to develop in that year. Low ice cover early in 
winter 2016 may have precluded the availability of sea-ice resources, and high values of both $\delta^{15} \mathrm{~N}$ and $\delta^{13} \mathrm{C}$ during this year could be explained by a combination of heterotrophic and detrital feeding (France 1995, Daly 2004). By August 2016, ice cover was similar to that in 2015, and larvae in 2015 and 2016 had similar lipid content, DI, and CI (Table 3). This suggests that larval diets in these years were similar at the time of sampling and influenced by marginal ice conditions resulting from the decrease in ice cover between July and August in 2015 and the late advance of ice in 2016.

\subsection{Environmental variables as predictors of differences in diet}

PC1, with which percent ice cover was highly correlated, explained less than half of the variability in diet and was not a significant predictor of any measured diet indicators. This was an unexpected result given the emphasis placed on the importance of sea ice for successful overwinter survival of krill, particularly larvae. We found differences in diet indicators in larvae among years that could be explained by feeding in sea ice; however, the ranges of values among years did not indicate entire trophic shifts in the presence of sea ice. Our results suggest that seaice biota was a supplementary rather than primary source of nutrition for overwintering krill, and that it had little predictive value for diet, particularly with respect to larvae.

Ample evidence from other studies suggests that larvae feed, at least in part, in the water column during winter. Overwinter strategies of krill vary regionally, and krill in the Bransfield Strait may benefit from low levels of primary production in the water column (in addition to benthic feeding) to survive the winter, especially in ice-free areas (Schmidt et al. 2014). Krill can also maintain positive growth at chl a concentrations less than $0.2 \mathrm{mg} \mathrm{m}^{-3}$ (Atkinson et al. 2006), which suggests that the importance of watercolumn resources should not be discounted for overwintering larvae at the latitudes of the northern Antarctic Peninsula where daylight occurs throughout winter. Higher carbon:chl ratios have been found in the water column than in ice in the Scotia Sea during winter despite low chl a concentrations in open water relative to the ice (Daly 1990), and sea ice did not contribute significantly to the food supply for larval krill in the western Antarctic Peninsula during 2 yr of contrasting ice development, when larvae were more concentrated in the water column than under the ice in both years (Daly 2004). Additionally, in east Antarctica, larvae were not dependent on sea-ice biota for overwinter survival and instead consumed a heterotrophic diet in the water column (Jia et al. 2016).

PC2 was highly correlated with chl $a$ and was the only PC that was a significant predictor of diet. In post-larvae, PC2 was positively correlated with lipid content, DI, and $\delta^{15} \mathrm{~N}$ (i.e. as chl a decreased, these diet indicators increased) (Fig. 6a,b,d). These data suggest that post-larvae were not feeding on sea-ice resources throughout winter. It is possible that post-larvae grazed on benthic resources once water-column chl a declined with the onset of winter (Kawaguchi et al. 1986, France 1995, Schmidt et al. 2014). However, while benthic feeding may explain increases in lipid content and $\delta^{15} \mathrm{~N}$, it does not explain the increase in DI with decreased chl $a$. The increase in DI may have been driven by results from 2016, when DI was highest (Table 3), and related to a rapid retreat of sea ice between August and September associated with an anomalous warming event (Turner et al. 2017, Stuecker et al. 2017). Our data show that UML temperature and UML depth in our survey area was not anomalously warm or shallow, respectively (Table 1, C. S. Reiss unpubl. data). Therefore, ice in our survey area was unlikely to have melted. It is possible that with the reduced sea-ice cover between August and September (Fig. 2a,b), water column primary production could have been sufficient to influence DI. Diatoms may rapidly optimize their growth in favorable conditions (i.e. reduced ice cover and increased light) (J. Iriarte pers. comm.), but with no concomitant increase in chl a with sea-ice retreat, we speculate that any increase in primary production may have been rapidly grazed.

In larvae, we found a significant positive relationship between PC2 and $\delta^{13} \mathrm{C}$ (i.e. as chl a decreased, $\delta^{13} \mathrm{C}$ increased) (Fig. 6d). Values of $\delta^{13} \mathrm{C}$ are generally used to distinguish feeding habitats, with ice habitats enriched in $\delta^{13} \mathrm{C}$ relative to open-water habitats (Frazer 1996); therefore, increased $\delta^{13} \mathrm{C}$ with decreased water column chl a could indicate that this relationship resulted from feeding on sea-ice biota when it was available. However, if this were the case, we would have expected to see relationships between diet indicators in larvae and sea-ice cover, which we did not observe. Additionally, Frazer (1996) found that elevated $\delta^{13} \mathrm{C}$ in larvae does not necessarily result from changes in diet. In our study, the majority (68\%) of larvae sampled were from the WA and EI sectors, where water column chl $a$ was highest 
every year, yet no other diet indicators were correlated with PC2. These results suggest that the relationships of diet to PC2 and chl a may reflect spatial differences in diet between post-larvae and larvae which cannot be resolved because of the significant interaction between year and sampling sector. Alternatively, as previously noted, these results suggest that the relationships between environmental factors and diet during winter are not straightforward and require further study.

\subsection{Caveats}

Although we did not measure $\delta^{13} \mathrm{C}$ and $\delta^{15} \mathrm{~N}$ in sea-ice biota or water column POM, compound-specific stable isotopes revealed no annual differences in the source carbon of $16: 1 n-7$ or $18: 4 n-3$, which were the fatty acids most likely to reflect the conditions we sampled during our survey (Kohlbach et al. 2017). We can therefore infer that observed differences in diet indicators were the result of differences in diet, rather than annual differences in carbon affecting primary production. Previous autumn and winter studies have reported $\delta^{15} \mathrm{~N}$ baseline values of -5 to $41 \%$ o for sea-ice biota and -8 to $6 \%$ for water column POM, suggesting a high degree of variability depending on location and year (Rau et al. 1991, Schmidt et al. 2003, Jia et al. 2016, Kohlbach et al. 2017). We observed few annual differences in the $\delta^{15} \mathrm{~N}$ of post-larvae, and values of $\delta^{15} \mathrm{~N}$ in larvae among all years of our study ranged from 3.4-6.4\%o, with higher values occurring in years with less sea ice. Larval growth rates are higher in autumn than in winter (Meyer et al. 2009), and Schmidt et al. (2003) found that $\delta^{15} \mathrm{~N}$ in small, fast-growing animals with high tissue turnover rates may closely match the $\delta^{15} \mathrm{~N}$ of the food web baseline. Therefore, values of $\delta^{15} \mathrm{~N}$ we obtained from larvae during winter are likely to closely reflect the isotopic baseline of their autumn feeding habitat.

Although we only considered percent ice cover in our analyses, several studies also suggest that ice complexity is an important factor in determining the quality of the ice habitat for krill. Ice with overrafted, deformed surfaces may provide concentrated sources of food and protection from predators (Frazer et al. 2002a, Meyer et al. 2009, 2017). Although we classified the ice type at each sampling station based on visual observations from the ship, our classification is not comparable to those developed from SCUBAbased observations (e.g. Frazer et al. 2002b, Meyer et al. 2017). Therefore, we were unable to conclude whether the krill sampled in our study benefitted from association with structurally complex ice. However, ice that we characterized as 'slush' or 'thin' was $<300 \mathrm{~mm}$ thick and unlikely to have the over-rafted, deformed surfaces thought to be important for overwintering larvae. Because even thin, newly formed ice may contain high abundances of sea-ice biota (Garrison 1991), we feel confident that using percent ice cover, rather than ice type, to describe the possible contribution of sea-ice biota to krill diet at each station was a prudent choice and resulted in a more accurate characterization of krill diet in relation to annual ice cover across the breadth of the northern Antarctic Peninsula.

\subsection{Annual recruitment success}

Summer studies of the length distributions of krill have been used to track the recruitment of cohorts among years (Siegel \& Loeb 1995, Loeb et al. 1997). Recruitment of small krill $(<33 \mathrm{~mm})$ has been positively correlated with regional winter sea-ice indices in many areas, especially along the Antarctic Peninsula (Siegel \& Loeb 1995, Loeb et al. 1997, 2009, Quetin et al. 2003, Saba et al. 2014), and is thought to be largely independent of krill biomass. Thus, we expected that because sea-ice cover was greatest during the winters of 2013 and 2015, significant recruitment should have occurred in 2014 and 2016.

However, the patterns of recruitment we observed were unexpected. For example, in 2013 larvae were in the 'best' condition of all our study years, as measured by their lipid content. Yet we observed just a small pulse of recruitment (post-larvae $<25 \mathrm{~mm}$ ) in 2014. We observed the highest proportional recruitment of larvae in 2014, which appeared as post-larvae $<30 \mathrm{~mm}$ in 2015. This was unexpected, given the suboptimal ice conditions in 2014 and evidence of high levels of heterotrophic feeding in the water column throughout the winter. We cannot discern from our data whether these recruits originated from larvae that were present in our study area during winter 2014, or whether they originated elsewhere (Siegel et al. 2003). However, we hypothesize that, despite marginal winter conditions in 2014, larval production in summer 2015 was high in our study area, as we observed the highest absolute larval abundances of all years in winter 2015 (Table 1). We thus expected to observe high proportional recruitment in 2016, since both larval abundance and sea-ice cover were high in 2015. However, we also observed few postlarvae $<30 \mathrm{~mm}$ during the last year of our surveys, 
suggesting that recruitment dynamics are more complex and cannot be explained by ice cover alone.

At least 2 possible explanations can account for low recruitment in 2016. First, it is possible that larvae did not survive the winter in 2015, despite higher ice cover. Presumably sea-ice biota would have been available to support the high abundances of larvae (although we did not measure chl $a$ in the ice), but a decline in ice cover from July to August 2015 may have negatively affected SIMCO biomass. In 2015, larvae had low lipid content, similar to levels observed in larvae from years of low ice cover. Despite high ice cover and abundance, larval condition may have been suboptimal and the mortality rate of larvae may have been sufficiently high after the survey to produce recruitment failure. Another plausible hypothesis is that larvae may have been advected to other areas of the Scotia Sea and appeared as recruits to the east of our survey area (Siegel 2005) because of a lack of suitable ice habitat for retaining larvae (Meyer et al. 2017). Given that only $26.5 \%$ of stations where larvae were collected during our study was covered by first-year or multi-year ice that may have provided sufficient habitat to retain larvae in the region (Table S1), considerable advective loss from the northern Antarctic Peninsula could have occurred. While our data are insufficient to discriminate between these 2 explanations, it is clear that the recruitment dynamics of krill in the northern Antarctic Peninsula are not just a function of the condition or abundance of larvae in late winter, furthering the argument that krill recruitment dynamics are more complex than hypothesized.

Our study did not reveal a simple relationship between extensive winter sea-ice cover and high recruitment success the following year despite the temporal proximity between larval sampling and when recruitment would have occurred, but this link has been well-established by others (e.g. Kawaguchi \& Satake 1994, Siegel \& Loeb 1995, Atkinson et al. 2004). Thus, the relationship between winter sea ice and long-term trends in recruitment may not be straightforward, especially in areas like the northern Antarctic Peninsula, which is changing rapidly. Cox et al. (2018) and Kinzey et al. (2018) found that, although sea ice has steadily decreased around the Antarctic Peninsula over the last 40 yr (Stammerjohn et al. 2008b, 2012), krill density in this region has remained stable over the same time scale, and recruitment has occurred at consistent intervals (Reiss 2016). However, Atkinson et al. (2019) found that krill density over the last $40 \mathrm{yr}$ around the peninsula has declined coincident with positive anomalies in the Southern Annular Mode (SAM), when warm northerly winds reduce sea-ice cover around the Antarctic Peninsula (Stammerjohn et al. 2008a, De Santis et al. 2017). Atkinson et al. (2019) argued that the observed stability in krill density is the result of an increase in the mean size of krill over time, despite numerical declines. More studies consisting of consecutive summer and winter seasons are necessary to refine our understanding of the mechanisms driving successful recruitment.

Our findings are consistent with the results of previous work that suggest krill may not fare as poorly as previously thought under future conditions of less sea ice, and that their habitat may even expand (Melbourne-Thomas et al. 2016). Future studies of krill, particularly larvae, should focus on multiple consecutive winters to ensure that appropriate spatial and temporal scales are sampled when predicting how krill will respond to a changing environment.

\section{CONCLUSIONS}

Antarctic krill, particularly larvae, are flexible with respect to feeding behavior and prey switching, and are able to survive and persist in the water column during winter while exploiting sea-ice resources when they are available. Given that krill have a plastic life history to accommodate variability in their environment, particularly in the northern Antarctic Peninsula region where ice dynamics are unpredictable among years and annual sea-ice duration has declined in recent decades (Stammerjohn et al. 2008a), the mechanisms in krill that may be driving complex responses to the environment may not be straightforward.

We conclude that flexibility in krill provides this species with multiple mechanisms to thrive in a multitude of environmental conditions. We also stress that, despite $4 \mathrm{yr}$ of consecutive study, we still cannot characterize with certainty how krill will respond to future ice reduction in the Southern Ocean. Future studies should ensure that appropriate spatial and temporal scales are sampled when making predictions about krill survival in a world with less sea ice.

Acknowledgements. We thank the crew and the scientific support staff of the National Science Foundation vessel RVIB 'Nathaniel B. Palmer'. We also thank all of the technicians over our 5 winters at sea for their hard work, enthusiasm, and dedication while collecting and processing sam- 
ples at sea, particularly Kim Dietrich, Ryan Driscoll, and Rachel Pound. We also thank Anthony Cossio for logistical support and Drs. Jefferson Hinke and Jeffrey Seminoff for helpful feedback during manuscript preparation.

\section{LITERATURE CITED}

Atkinson A, Meyer B, Stübing D, Hagen W, Schmidt K, Bathmann UV (2002) Feeding and energy budgets of Antarctic krill Euphausia superba at the onset of winter-II. Juveniles and adults. Limnol Oceanogr 47: 953-966

Atkinson A, Siegel V, Pakhomov E, Rothery P (2004) Longterm decline in krill stock and increase in salps within the Southern Ocean. Nature 432:100-103

Atkinson A, Shreeve RS, Hirst AG, Rothery P and others (2006) Natural growth rates in Antarctic krill (Euphausia superba): II. Predictive models based on food, temperature, body length, sex, and maturity stage. Limnol Oceanogr 51:973-987

Atkinson A, Hill SL, Pakhomov EA, Siegel V and others (2019) Krill (Euphausia superba) distribution contracts southward during rapid regional warming. Nat Clim Change 9:142-147

Bernard KS, Gunther LA, Mahaffey SH, Qualls KM and others (2018) The contribution of ice algae to the winter energy budget of juvenile Antarctic krill in years with contrasting sea ice conditions. ICES J Mar Sci 76: 206-216

Budge SM, Iverson SJ, Koopman HN (2006) Studying trophic ecology in marine ecosystems using fatty acids: a primer on analysis and interpretation. Mar Mamm Sci 22: 759-801

Cox MJ, Candy S, de la Mare WK, Nicol S, Kawaguchi S, Gales N (2018) No evidence for a decline in the density of Antarctic krill Euphausia superba Dana, 1850, in the Southwest Atlantic sector between 1976 and 2016. J Crustac Biol 38:656-661

Daly KL (1990) Overwintering development, growth, and feeding of larval Euphausia superba in the Antarctic marginal ice zone. Limnol Oceanogr 35:1564-1576

* Daly KL (2004) Overwintering growth and development of larval Euphausia superba: an interannual comparison under varying environmental conditions west of the Antarctic Peninsula. Deep Sea Res II 51:2139-2168

de la Mare WK (1994) Estimating krill recruitment and its variability. CCAMLR Sci 1:55-69

* De Santis A, Maier E, Gomez R, Gonzalez I (2017) Antarctica, 1979-2016 sea ice extent: total versus regional trends, anomalies, and correlation with climatological variables. Int J Remote Sens 38:7566-7584

Falk-Petersen S, Hagen W, Kattner G, Clarke A, Sargent J (2000) Lipids, trophic relationships, and biodiversity in Arctic and Antarctic krill. Can J Fish Aquat Sci 57: 178-191

* Flores H, van Franeker JA, Siegel V, Haraldsson M and others (2012) The association of Antarctic krill Euphausia superba with the under-ice habitat. PLOS ONE 7:e31775

Flores H, Hunt BPV, Kruse S, Pakhomov EA and others (2014) Seasonal changes in the vertical distribution and community structure of Antarctic macrozooplankton and micronekton. Deep Sea Res I 84:127-141

Folch J, Lees M, Sloane Stanley GH (1957) A simple method for the isolation and purification of total lipides from animal tissues. J Biol Chem 226:497-509
France RL (1995) Carbon-13 enrichment in benthic compared to planktonic algae: foodweb implications. Mar Ecol Prog Ser 124:307-312

Frazer TK (1996) Stable isotope composition $\left(\delta^{13} \mathrm{C}\right.$ and $\left.\delta^{15} \mathrm{~N}\right)$ of larval krill, Euphausia superba, and two of its potential food sources in winter. J Plankton Res 18:1413-1426

F Frazer TK, Ross RM, Quetin LB, Montoya JP (1997) Turnover of carbon and nitrogen during growth of larval krill, Euphausia superba Dana: a stable isotope approach. J Exp Mar Biol Ecol 212:259-275

Frazer TK, Quetin LB, Ross RM (2002a) Abundance, sizes and developmental stages of larval krill, Euphausia superba, during winter in ice-covered seas west of the Antarctic Peninsula. J Plankton Res 24:1067-1077

* Frazer TK, Quetin LB, Ross RM (2002b) Energetic demands of larval krill, Euphausia superba, in winter. J Exp Mar Biol Ecol 277:157-171

F Fritsen CH, Memmott J, Stewart FJ (2008) Inter-annual seaice dynamics and micro-algal biomass in winter pack ice of Marguerite Bay, Antarctica. Deep Sea Res II 55: 2059-2067

Garrison DL (1991) Antarctic sea ice biota. Am Zool 31: 17-33

KGarrison DL, Close AR (1993) Winter ecology of the sea ice biota in Weddell Sea pack ice. Mar Ecol Prog Ser 96: $17-31$

*Garrison DL, Buckt KR, Gowing MM (1993) Winter plankton assemblage in the ice edge zone of the Weddell and Scotia Seas: composition, biomass and spatial distributions. Deep Sea Res I 40:311-338

*Hagen W, Kattner G, Terbrüggen A, Van Vleet ES (2001) Lipid metabolism of the Antarctic krill Euphausia superba and its ecological implications. Mar Biol 139: 95-104

*Harangozo SA (2006) Atmospheric circulation impacts on winter maximum sea ice extent in the west Antarctic Peninsula region (1979-2001). Geophys Res Lett 33:L02502

Hilditch TP, Williams PN (1964) The chemical constitution of natural fats, $4^{\text {th }}$ edn. Chapman \& Hall, London

Holm-Hansen O, Lorenzen CJ, Holmes RW, Strickland JDH (1965) Fluorometric determination of chlorophyll. ICES J Mar Sci 30:3-15

*Huntley ME, Nordhausen W, Lopez MDG (1994) Elemental composition, metabolic activity and growth of Antarctic krill Euphausia superba during winter. Mar Ecol Prog Ser 107:23-40

Jia Z, Swadling KM, Meiners KM, Kawaguchi S, Virtue P (2016) The zooplankton food web under East Antarctic pack ice - A stable isotope study. Deep Sea Res II 131: 189-202

Kawaguchi S, Satake M (1994) Relationship between recruitment of the Antarctic krill and the degree of ice cover near the South Shetland Islands. Fish Sci 60: 123-124

* Kawaguchi S, Matsuda O, Ishikawa S, Naito Y (1986) A light trap to collect krill and other micronektonic and planktonic animals under the Antarctic coastal fast ice. Polar Biol 6:37-42

Kinzey D, Watters G, Reiss C (2018) Parameter estimation using randomized phases in an integrated assessment model for Antarctic krill. PLOS ONE 13:e0202545

Kohlbach D, Lange BA, Schaafsma FL, David C and others (2017) Ice algae-produced carbon is critical for overwintering of Antarctic krill Euphausia superba. Front Mar Sci $4: 310$ 
Le Fevre J, Legendre L, Rivkin RB (1998) Fluxes of biogenic carbon in the Southern Ocean: roles of large microphagous zooplankton. J Mar Syst 17:325-345

Loeb V, Siegel V, Holm-Hansen O, Hewitt R, Fraser W, Trivelpiece W, Trivelpiece S (1997) Effects of sea-ice extent and krill or salp dominance on the Antarctic food web. Nature 387:897-900

Loeb VJ, Hofmann EE, Klinck JM, Holm-Hansen O, White WB (2009) ENSO and variability of the Antarctic peninsula pelagic marine ecosystem. Antarct Sci 21:135-148

Lowe AT, Ross RM, Quetin LB, Vernet M, Fritsen CH (2012) Simulating larval Antarctic krill growth and condition factor during fall and winter in response to environmental variability. Mar Ecol Prog Ser 452:27-43

Makarov RR, Denys C (1981) Stages of sexual maturity of Euphausia superba Dana. BIOMASS Handbook Series 11:1-13

Marschall HP (1988) The overwintering strategy of Antarctic krill under the pack-ice of the Weddell Sea. Polar Biol 9: 129-135

Mauchline J (1980) Measurement of body length of Euphausia superba Dana. BIOMASS Handbook Series 4:1-9

Melbourne-Thomas J, Corney SP, Trebilco R, Meiners KM and others (2016) Under ice habitats for Antarctic krill larvae: Could less mean more under climate warming? Geophys Res Lett 43:10322-10327

Meyer B (2012) The overwintering of Antarctic krill, Euphausia superba, from an ecophysiological perspective. Polar Biol 35:15-37

Meyer B, Atkinson A, Stübing D, Oettl B, Hagen W, Bathmann UV (2002) Feeding and energy budgets of Antarctic krill Euphausia superba at the onset of winter-I. Furcilia III larvae. Limnol Oceanogr 47:943-952

Meyer B, Fuentes V, Guerra C, Schmidt K and others (2009) Physiology, growth, and development of larval krill Euphausia superba in autumn and winter in the Lazarev Sea, Antarctica. Limnol Oceanogr 54:1595-1614

Meyer B, Auerswald L, Siegel V, Spahic S and others (2010) Seasonal variation in body composition, metabolic activity, feeding, and growth of adult krill Euphausia superba in the Lazarev Sea. Mar Ecol Prog Ser 398:1-18

Meyer B, Freier U, Grimm V, Groeneveld J and others (2017) The winter pack-ice zone provides a sheltered but foodpoor habitat for larval Antarctic krill. Nat Ecol Evol 1: 1853-1861

Mitchell BG, Holm-Hansen O (1991) Observations and modeling of the Antarctic phytoplankton crop in relation to mixing depth. Deep-Sea Res 38:981-1007

Nicol S, Pauly T, Bindoff NL, Wright S and others (2000) Ocean circulation off east Antarctica affects ecosystem structure and sea-ice extent. Nature 406:504-507

Nicol S, Foster J, Kawaguchi S (2011) The fishery for Antarctic krill - recent developments. Fish Fish 13:30-40

Quetin LB, Ross RM (1991) Behavioral and physiological characteristics of the Antarctic krill, Euphausia superba. Am Zool 31:49-63

Quetin LB, Ross RM (2003) Episodic recruitment in Antarctic krill Euphausia superba in the Palmer LTER study region. Mar Ecol Prog Ser 259:185-200

Quetin LB, Ross RM (2009) Life under Antarctic pack ice: a krill perspective. In: Krupnik I, Lang MA, Miller SE (eds) Smithsonian at the poles. Smithsonian Institution Scholarly Press, Washington, DC, p 285-298

* Quetin LB, Ross RM, Frazer TK, Amsler MO, Wyatt-Evens C, Oakes SA (2003) Growth of larval krill, Euphausia superba, in fall and winter west of the Antarctic Peninsula. Mar Biol 143:833-843

Quetin LB, Ross RM, Fritsen CH, Vernet M (2007) Ecological responses of Antarctic krill to environmental variability: Can we predict the future? Antarct Sci 19:253-266

R Core Team (2019) R: A language and environment for statistical computing. R Foundation for Statistical Computing, Vienna. www.R-project.org/

Rau GH, Sullivan CW, Gordon LI (1991) $\delta^{13} \mathrm{C}$ and $\delta^{15} \mathrm{~N}$ variations in Weddell Sea particulate organic matter. Mar Chem 35:355-369

Reiss C (2008) Updated krill recruitment data for the Elephant Island region of the South Shetland Islands, Antarctica; 2002-2008. Report No. WG-EMM-08/41. Commission for the Conservation of Antarctic Marine Living Resources (CCAMLR), Hobart

Reiss CS (2016) Age, growth, mortality, and recruitment of Antarctic krill, Euphausia superba. In: Siegel V (ed) Biology and ecology of Antarctic krill, $1^{\text {st }}$ edn. Springer, Cham, p 101-144

Reiss CS, Walsh J, Goebel ME (2015) Winter preconditioning determines feeding ecology of Euphausia superba in the Antarctic peninsula. Mar Ecol Prog Ser 519:89-101

Reiss CS, Cossio A, Santora JA, Dietrich KS and others (2017) Overwinter habitat selection by Antarctic krill under varying sea-ice conditions: implications for top predators and fishery management. Mar Ecol Prog Ser 568:1-16

Ross RM, Quetin LB (1991) Ecological physiology of larval euphausiids, Euphausia superba (Euphausiacea). Mem Queensl Mus 31:321-333

Saba GK, Fraser WR, Saba VS, Iannuzzi RA and others (2014) Winter and spring controls on the summer food web of the coastal West Antarctic Peninsula. Nat Commun 5:4318

Karkar D (2008) Lattice: Multivariate data visualization with R. Springer, New York, NY

Schaafsma FL, Kohlbach D, David C, Lange BA, Graeve M, Flores H, van Franeker JA (2017) Spatio-temporal variability in the winter diet of larval and juvenile Antarctic krill, Euphausia superba, in ice-covered waters. Mar Ecol Prog Ser 580:101-115

Schmidt K, Atkinson A, Stübing D, McClelland JW, Montoya JP, Voss M (2003) Trophic relationships between Southern Ocean copepods and krill: some uses and limitations of a stable isotope approach. Limnol Oceanogr 48: $277-287$

Schmidt K, Atkinson A, Petzke KJ, Voss M, Pond DW (2006) Protozoans as a food source for Antarctic krill, Euphausia superba: complementary insights from stomach content, fatty acids, and stable isotopes. Limnol Oceanogr 51: $2409-2427$

Schmidt K, Atkinson A, Pond DW, Irel LC (2014) Feeding and overwintering of Antarctic krill across its major habitats: the role of sea ice cover, water depth, and phytoplankton abundance. Limnol Oceanogr 59:17-36

Siegel V (1989) Winter and spring distribution and status of the krill stock in Antarctic Peninsula waters. Arch FischWiss 39:45-72

Siegel V (2005) Distribution and population dynamics of Euphausia superba: summary of recent findings. Polar Biol 29:1-22

Siegel V (2012) Krill stocks in high latitudes of the Antarctic Lazarev Sea: seasonal and interannual variation in distribution, abundance and demography. Polar Biol 35: 1151-1177 
Siegel V, Loeb V (1995) Recruitment of Antarctic krill Euphausia superba and possible causes for its variability. Mar Ecol Prog Ser 123:45-56

Siegel V, Bergström B, Strömberg JO, Schalk PH (1990) Distribution, size frequencies and maturity stages of krill, Euphausia superba, in relation to sea-ice in the northern Weddell Sea. Polar Biol 10:549-557

Siegel V, Ross RM, Quetin LB (2003) Krill (Euphausia superba) recruitment indices from the western Antarctic Peninsula: Are they representative of larger regions? Polar Biol 26:672-679

Stammerjohn SE, Martinson DG, Smith RC, Iannuzzi RA (2008a) Sea ice in the western Antarctic Peninsula region: spatio-temporal variability from ecological and climate change perspectives. Deep Sea Res II 55:2041-2058

Stammerjohn SE, Martinson DG, Smith RC, Yuan X, Rind D (2008b) Trends in Antarctic annual sea ice retreat and advance and their relation to El Niño-Southern Oscillation and Southern Annular Mode variability. J Geophys Res 113:C03S90

Stammerjohn S, Massom R, Rind D, Martinson D (2012) Regions of rapid sea ice change: An inter-hemispheric seasonal comparison. Geophys Res Lett 39:L06501

Stowasser G, Atkinson A, McGill RAR, Phillips RA, Collins MA, Pond DW (2012) Food web dynamics in the Scotia Sea in summer: a stable isotope study. Deep Sea Res II 59-60:208-221

Stretch JJ, Hamner PP, Hamner WM, Michel WC, Cook J, Sullivan CW (1988) Foraging behavior of Antarctic krill Euphausia superba on sea ice microalgae. Mar Ecol Prog Ser 44:131-139

Editorial responsibility: James McClintock, Birmingham, Alabama, USA
Stübing D, Hagen W (2003) Fatty acid biomarker ratiosSuitable trophic indicators in Antarctic euphausiids? Polar Biol 26:774-782

Stübing D, Hagen W, Schmidt K (2003) On the use of lipid biomarkers in marine food web analyses: an experimental case study on the Antarctic krill, Euphausia superba. Limnol Oceanogr 48:1685-1700

Stuecker MF, Bitz CM, Armour KC (2017) Conditions leading to the unprecedented low Antarctic sea ice extent during the 2016 austral spring season. Geophys Res Lett 44:9008-9019

* Turner J, Phillips T, Marshall GJ, Hosking JS, Pope JO, Bracegirdle TJ, Deb P (2017) Unprecedented springtime retreat of Antarctic sea ice in 2016. Geophys Res Lett 44: 6868-6875

Vernet M, Martinson D, Iannuzzi R, Stammerjohn S and others (2008) Primary production within the sea-ice zone west of the Antarctic Peninsula: I-Sea ice, summer mixed layer, and irradiance. Deep Sea Res II 55: 2068-2085

Virtue P, Meyer B, Freier U, Nichols PD and others (2016) Condition of larval (furcilia VI) and one year old juvenile Euphausia superba during the winter-spring transition in East Antarctica. Deep Sea Res II 131:182-188

*Wickham H (2016) ggplot2: Elegant Graphics for Data Analysis. Springer-Verlag, New York, NY

Worby A, Allison I, (1999) A technique for making shipbased observations of Antarctic sea ice thickness and characteristics. Part I: observational technique and results. Research Report No. 14. Antarctic Cooperative Research Center, University of Tasmania, Hobart

Submitted: November 1, 2019; Accepted: April 7, 2020 Proofs received from author(s): May 16, 2020 